\title{
Plant and fungal products that extend lifespan in Caenorhabditis elegans
}

\author{
Jan Martel ${ }^{1,2}$, Cheng-Yeu Wu ${ }^{1-3}$, Hsin-Hsin Peng ${ }^{1,2,4}$, Yun-Fei Ko ${ }^{2,5,6}$, Hung-Chi Yang ${ }^{7}$ John D. Young ${ }^{5}$ and \\ David M. Ojcius ${ }^{1,2,8, *}$ \\ ${ }^{1}$ Center for Molecular and Clinical Immunology, Chang Gung University, Taoyuan, Taiwan. \\ ${ }^{2}$ Chang Gung Immunology Consortium, Chang Gung Memorial Hospital at Linkou, Taoyuan, Taiwan. \\ ${ }^{3}$ Research Center of Bacterial Pathogenesis, Chang Gung University, Taoyuan, Taiwan. \\ ${ }^{4}$ Laboratory Animal Center, Chang Gung Memorial Hospital at Linkou, Taoyuan, Taiwan. \\ ${ }^{5}$ Chang Gung Biotechnology Corporation, Taipei, Taiwan. \\ ${ }^{6}$ Biochemical Engineering Research Center, Ming Chi University of Technology, New Taipei City, Taiwan. \\ ${ }^{7}$ Department of Medical Laboratory Science and Biotechnology, Yuanpei University of Medical Technology, Hsinchu, Taiwan. \\ ${ }^{8}$ Department of Biomedical Sciences, University of the Pacific, Arthur Dugoni School of Dentistry, San Francisco, CA, USA. \\ * Corresponding Author: \\ David M. Ojcius, Department of Biomedical Sciences, University of the Pacific, Arthur Dugoni School of Dentistry, 155 Fifth Street, \\ San Francisco, CA 94103, USA; Phone: 1-415-780-2095; E-mail: dojcius@pacific.edu
}

\begin{abstract}
The nematode Caenorhabditis elegans is a useful model to study aging due to its short lifespan, ease of manipulation, and available genetic tools. Several molecules and extracts derived from plants and fungi extend the lifespan of $\boldsymbol{C}$. elegans by modulating aging-related pathways that are conserved in more complex organisms. Modulation of aging pathways leads to activation of autophagy, mitochondrial biogenesis and expression of antioxidant and detoxifying enzymes in a manner similar to caloric restriction. Low and moderate concentrations of plant and fungal molecules usually extend lifespan, while high concentrations are detrimental, consistent with a lifespan-modulating mechanism involving hormesis. We review here molecules and extracts derived from plants and fungi that extend the lifespan of $\boldsymbol{C}$. elegans, and explore the possibility that these natural substances may produce health benefits in humans.
\end{abstract}

doi: $10.15698 / \mathrm{mic} 2020.10 .731$

Received originally: 23.04.2020;

in revised form: 23.06.2020,

Accepted 25.06.2020,

Published 09.07.2020.

Keywords: autophagy, caloric restriction mimetics, dietary supplements, hormesis, phytochemicals.
Abbreviations:
$C R$-caloric restriction;
EGCG - epigallocatechin gallate;
HSP - heat shock protein;
$R O S$ - reactive oxygen species;
$T O R$-target of rapamycin.

\section{INTERVENTIONS TO DELAY AGING}

Aging can be modulated by genes and lifestyle. For instance, specific gene variants of insulin-like growth factor-1 (IGF-1) receptor and forkhead box O3A (FOXO3A) are associated with longer lifespan in centenarians [1]. In terms of lifestyle, one of the most studied interventions that delay aging is caloric restriction (CR), which can increase lifespan in organisms ranging from yeasts to primates [2]. Diet composition also influences the aging process, with lowprotein diets $[3,4]$ and high phytochemical intake $[5,6]$ being associated with a longer lifespan. Notably, a recent analysis suggests that the heritability of human longevity is below $10 \%$ [7], indicating that lifestyle choices play a major role in influencing aging and longevity.
Since interventions such as CR and dieting are difficult to implement and maintain over a long period, interest has focused on identifying molecules that produce effects similar to CR (i.e., the CR mimetics). This endeavor is based on the observation that signaling pathways that are modulated by CR, including $5^{\prime}$ adenosine-monophosphate-activated protein kinase (AMPK), mammalian target of rapamycin (mTOR) and sirtuin-1, can be targeted by small organic compounds [8]. Activation of these pathways induces autophagy, mitochondrial biogenesis and expression of antioxidant and detoxifying enzymes, which together can improve cellular function $[2,9,10]$. In a manner similar to $C R$, several organic compounds labeled as CR mimetics promote physiological functions and reduce the development 
of chronic diseases, thus improving both health and longevity [8].

The nematode Caenorhabditis elegans is a useful model organism for studying aging [11] (Figure 1). One of the main advantages of $C$. elegans is its short lifespan of about 20 to 25 days, allowing the rapid screening of substances that affect longevity. In addition, nematodes can be manipulated easily and single-gene deletion mutants are readily available, which facilitates the identification of signaling pathways involved in lifespan extension. Furthermore, many cellular pathways that control aging in C. elegans are conserved in more complex organisms, including fruit flies, mice and humans [12]. Modulation of the gut microbiota can also positively or negatively influence health and longevity in C. elegans $[13,14]$. We review here the molecules and extracts derived from plants and fungi that are known to extend the lifespan of $C$. elegans, and discuss the possibility of using these substances in humans.

\section{PLANT AND FUNGAL MOLECULES THAT EXTEND LIFESPAN IN C. ELEGANS}

A survey of the literature indicates that a large number of molecules and extracts from plants and fungi extend the lifespan of $C$. elegans (Table 1). Many of these natural substances are consumed in the human diet, and are found in vegetables, fruits, mushrooms, spices, tea, coffee and wine, while other extracts are derived from herbal and fungal remedies used in traditional Chinese medicine (e.g., Ganoderma lucidum, Ginkgo biloba, and Rhodiola rosea). Some pharmaceutical drugs were originally derived from plants and fungi, such as acetylsalicylic acid (aspirin), lovastatin and metformin, as well as molecules that were isolated from herbal remedies, including celastrol, huperzine $A$ and triptolide (Table 1). In addition, many of the plant and fungal extracts and molecules included here are used as dietary supplements (e.g., Antrodia cinnamomea, glucosamine, propolis, quercetin and resveratrol).
While many natural substances can extend the lifespan of nematodes, they act by regulating a small set of cellular pathways (Table 1 and Figure 2). One of the main cellular pathways that control $C$. elegans lifespan is the insulin pathway induced by food intake $[12,15]$. This pathway consists of DAF-2 (the homolog of the human insulin receptor), several conserved protein kinases, and DAF-16 (the sole homolog of the FOXO family of transcription factors; Figure 2). In nematodes, insulin-like peptides bind to DAF-2 and induce intracellular signaling that leads to phosphorylation of DAF-16, thereby sequestering the transcription factor in the cytoplasm; in the absence of insulin-like peptides and DAF-2 signaling, as occurs when food is scarce, DAF-16 migrates into the nucleus where it induces expression of several genes including heat-shock proteins (HSPs) and antioxidant enzymes like superoxide dismutase (SOD) and catalase (CAT), as well as autophagy-related proteins (Figure 2) [12, 15].

Another pathway activated by food intake involves the target of rapamycin (TOR), which is activated by nutrients and amino acids (Figure 2). Inhibition of TOR activates skinhead 1 (SKN-1), the homolog of nuclear factor erythroid-2related factor (Nrf) proteins, and defective pharyngeal development protein 4 (PHA-4), the homolog of human FOXA proteins, leading to expression of detoxifying enzymes and activation of autophagy, respectively [12]. TOR inhibition also activates autophagy by inducing basic helix-loop-helix protein 30 (HLH-30), the homolog of $\mathrm{HLH}$ transcription factor EB (TFEB) [16]. In addition, the nicotinamide adenine dinucleotide $\left(\mathrm{NAD}^{+}\right)$-dependent protein deacetylase Sir-2.1, the homolog of human sirtuin-1, induces anti-aging effects at least in part by stimulating DAF-16 activity (Figure 2).

Phytochemicals were previously believed to produce beneficial effects on health and longevity mainly by acting as antioxidants that scavenge reactive oxygen species (ROS).
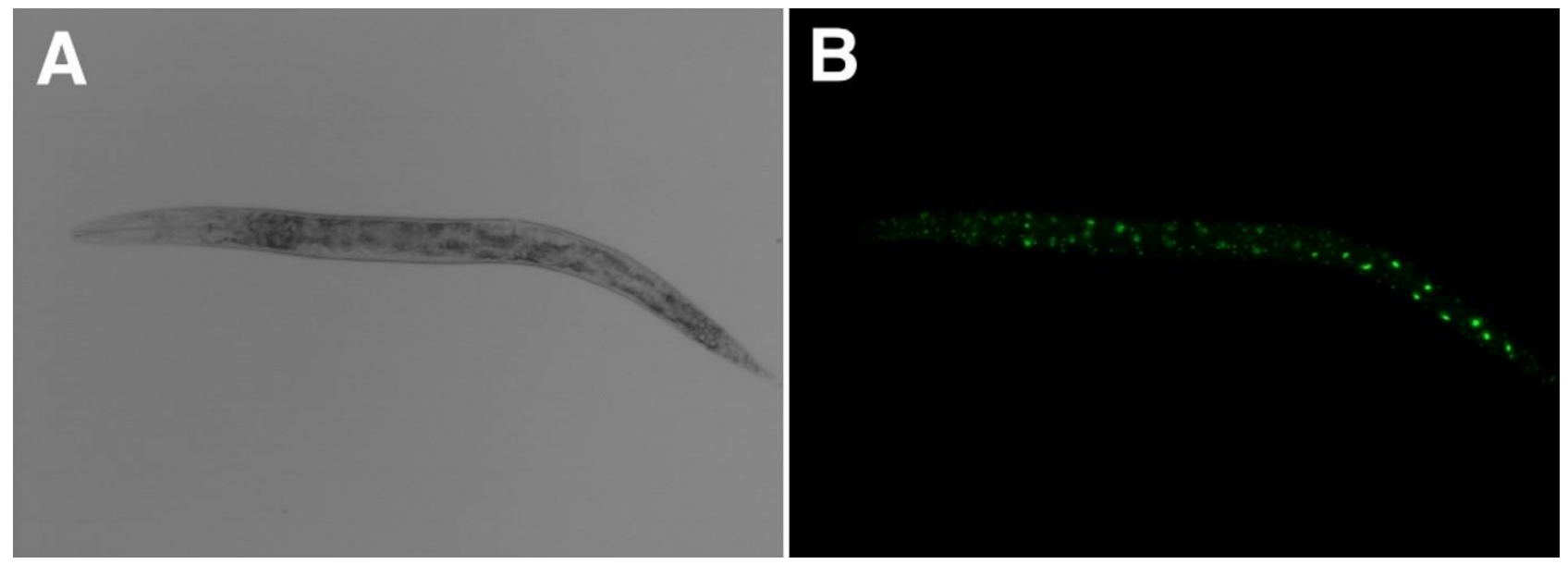

FIGURE 1: Images of C. elegans nematode used as a model to study aging and longevity. (A) Light microscopy and (B) fluorescence microscopy images of transgenic $C$. elegans strain CGUIS-1 expressing the nucleolar protein fibrillarin 1 (FIB-1) coupled to green fluorescent protein (GFP). FIB-1 is a marker of nucleolus size that negatively correlates with longevity across taxa [161], making the CGUIS-1 strain useful for screening natural products that may extend lifespan. In B, GFP auto-fluorescence is induced by ultraviolet light. The images are unpublished observations made by the authors. 
TABLE 1. Examples of naturally-occurring substances and related pharmaceutical drugs that extend C. elegans lifespan.

\begin{tabular}{|c|c|c|c|c|c|c|}
\hline Substance & $\begin{array}{l}\text { Chemical } \\
\text { Class }\end{array}$ & Source & $\begin{array}{l}\text { Mechanism } \\
\text { (or Gene Involved) }\end{array}$ & $\begin{array}{l}\text { Mean } \\
\text { Lifespan }\end{array}$ & $\begin{array}{l}\text { Maximum } \\
\text { Lifespan }\end{array}$ & Ref. \\
\hline $\begin{array}{l}\text { Acetylsalicylic acid (aspi- } \\
\text { rin) }\end{array}$ & Organic acid & $\begin{array}{l}\text { Analgesic drug (de- } \\
\text { rived from willow } \\
\text { bark) }\end{array}$ & $\begin{array}{l}\text { AAK-2/AMPK } \uparrow, \\
\text { DAF-16个, SOD-3个, } \\
\text { ROS } \downarrow\end{array}$ & $\begin{array}{l}+23 \% \\
\text { (ROS) }\end{array}$ & & {$[21,22]$} \\
\hline Antcin M & Terpenoid & $\begin{array}{l}\text { Antrodia cin- } \\
\text { namomea }\end{array}$ & ROS $\downarrow$ & $+7 \%$ & & [47] \\
\hline Aspalathin & $\begin{array}{l}\text { Chalcone } \\
\text { glycoside }\end{array}$ & Rooibos tea & DAF-16个, ROS $\downarrow$ & $\begin{array}{l}+24 \% \text { (high } \\
\text { glucose } \\
\text { only) }\end{array}$ & & [48] \\
\hline Baicalein & Flavonoid & $\begin{array}{l}\text { Scutellaria bai- } \\
\text { calensis }\end{array}$ & SKN-1个 & $+45 \%$ & $+24 \%$ & {$[49,50]$} \\
\hline Betalains & Indole & Opuntia fruit & ROS $\downarrow$ & $+34 \%$ & & [51] \\
\hline Boeravinone B & Rotenoid & Boerhaavia diffusa & DAF-16个, SKN-1个 & $+28 \%$ & & {$[52]$} \\
\hline Brazilin & Flavonoid & Caesalpinia sappan & $\begin{array}{l}\text { DAF-16个, HSP- } \\
16.2 \downarrow, \text { SOD-3个, } \\
\text { ROS } \downarrow\end{array}$ & $+18 \%$ & & {$[53]$} \\
\hline Caffeic acid & Polyphenol & Plants & $\begin{array}{l}\text { DAF-16个, Sir-2.1, } \\
\text { OSR-1 }\end{array}$ & $+15 \%$ & & {$[54]$} \\
\hline Caffeic acid phenyl ester & Polyphenol & Propolis & DAF-16个 & $\begin{array}{l}+9 \% \\
\text { (median) }\end{array}$ & $+17 \%$ & {$[55]$} \\
\hline Caffeine & Alkaloid & Coffee & DAF-16个, CBP-1 & $+37 \%$ & $+52 \%$ & $\begin{array}{l}{[19,} \\
56-58]\end{array}$ \\
\hline Calycosin & Isoflavone & $\begin{array}{l}\text { Astragalus mem- } \\
\text { branaceus }\end{array}$ & DAF-2, DAF-16个 & $+25 \%$ & & {$[59]$} \\
\hline Carnosic acid & Terpenoid & $\begin{array}{l}\text { Rosmarinus offici- } \\
\text { nalis }\end{array}$ & $\begin{array}{l}\text { SOD-3个, SKN-1个, } \\
\text { HSF-1个 }\end{array}$ & $+16 \%$ & $+22 \%$ & {$[60]$} \\
\hline Carnosol & Terpenoid & R. officinalis & SOD-3个, ROS $\downarrow$ & $+19 \%$ & $+26 \%$ & [35] \\
\hline Catechin & Flavonoid & Green tea & DAF-2 & $+15 \%$ & & {$[61,62]$} \\
\hline Celastrol & Terpenoid & $\begin{array}{l}\text { Tripterygium wil- } \\
\text { fordii }\end{array}$ & ND & $+17 \%$ & & [63] \\
\hline Chlorogenic acid & Polyphenol & Coffee & $\begin{array}{l}\text { DAF-2, DAF-16个, } \\
\text { SKN-1个 }\end{array}$ & $+20 \%$ & & [34] \\
\hline Chlorophyll & Chlorin & Vegetables & DAF-16个 & $+26 \%$ & & {$[64]$} \\
\hline Curcumin & Polyphenol & Turmeric & Sir-2.1, OSR-1 & $\begin{array}{l}+55 \% \\
\text { (median) }\end{array}$ & & {$[65,66]$} \\
\hline Damaurone D & Flavonoid & Damask rose & $\begin{array}{l}\text { DAF-2, DAF-16个, } \\
\text { SOD-3个 }\end{array}$ & $+17 \%$ & $+21 \%$ & [67] \\
\hline Dehydroabietic acid & Terpenoid & Conifer resin & Sir-2.1 & $+16 \%$ & & [68] \\
\hline Diallyl trisulfide & $\begin{array}{l}\text { Organosul- } \\
\text { fur }\end{array}$ & Garlic & SKN-1个 & $+13 \%$ & & {$[69]$} \\
\hline Diosgenin & Terpenoid & Plants & DAF-16个, SOD-3个 & $+20 \%$ & & [70] \\
\hline 4,4'-Dimethoxychalcone & Chalcone & $\begin{array}{l}\text { Angelica keiskei } \\
\text { koidzumi }\end{array}$ & Autophagy $\uparrow$ & $\begin{array}{l}+20 \% \\
\text { (median) }\end{array}$ & & {$[71]$} \\
\hline Emodin & $\begin{array}{l}\text { Anthraqui- } \\
\text { none }\end{array}$ & Rhubarb, buckthorn & Sir-2.1, DAF-16个 & $+20 \%$ & & [77] \\
\hline Ellagic acid & Phenol & Fruits & DAF-16个 & $+11 \%$ & & {$[62,78]$} \\
\hline Ferulsinaic acid & Organic acid & Ferula plants & AGEs $\downarrow$, ROS $\downarrow$ & $+18 \%$ & $+42 \%$ & [79] \\
\hline Fisetin & Flavonoid & Fruits, vegetables & DAF-16个, ROS $\downarrow$ & $+6 \%$ (heat) & & {$[80]$} \\
\hline Flavonoids & Flavonoid & Onion & ND & $+20 \%$ & & [17] \\
\hline Fruit extract & Mixture & Apple & ND & $+39 \%$ & $+25 \%$ & [81] \\
\hline Fruit extract & Mixture & Blueberry & $\begin{array}{l}\text { DAF-16个, SKN-1个, } \\
\text { SOD-3个 }\end{array}$ & $+44 \%$ & $+24 \%$ & {$[82]$} \\
\hline Fruit extract & Mixture & Mulberry & DAF-16个, Sir-2.1 & $+20 \%$ & $+9 \%$ & [83] \\
\hline Fruit extract & Mixture & Orange & $\begin{array}{l}\text { DAF-16个, SOD-3个, } \\
\text { ROS } \downarrow\end{array}$ & $+26 \%$ & $+26 \%$ & {$[84]$} \\
\hline Fruit extract & Mixture & Pomegranate & DAF-16个 & $+56 \%$ & $+36 \%$ & [78] \\
\hline Fruit extract & Mixture & Purple pitanga & DAF-16个 & ND & & {$[85]$} \\
\hline Fungal extract & Mixture & Ganoderma lucidum & GLP-1 & $+36 \%$ & $+12 \%$ & [86] \\
\hline
\end{tabular}


TABLE 1 (continued). Examples of naturally-occurring substances and related pharmaceutical drugs that extend C. elegans lifespan.

\begin{tabular}{|c|c|c|c|c|c|c|}
\hline Substance & $\begin{array}{l}\text { Chemical } \\
\text { Class }\end{array}$ & Source & $\begin{array}{l}\text { Mechanism } \\
\text { (or Gene Involved) }\end{array}$ & $\begin{array}{l}\text { Mean } \\
\text { Lifespan }\end{array}$ & $\begin{array}{l}\text { Maximum } \\
\text { Lifespan }\end{array}$ & Ref. \\
\hline Gallic acid & $\begin{array}{l}\text { Phenolic } \\
\text { acid }\end{array}$ & Fruits & ND & $+12 \%$ & & {$[62]$} \\
\hline Genistein & Isoflavone & Soybean, coffee & SOD-3个, HSP-16.2个 & $+28 \%$ & & [87] \\
\hline Glucosamine & $\begin{array}{l}\text { Amino sug- } \\
\text { ar }\end{array}$ & $\begin{array}{l}\text { Dietary supplement } \\
\text { (can be isolated } \\
\text { from wheat or corn) }\end{array}$ & 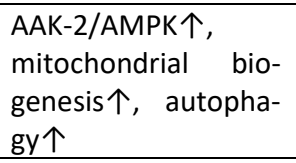 & $+30 \%$ & & {$[30,88]$} \\
\hline Glaucarubinone & $\begin{array}{l}\text { Degraded } \\
\text { terpenoid }\end{array}$ & $\begin{array}{l}\text { Simaroubaceae } \\
\text { plants }\end{array}$ & Cellular respiration $\uparrow$ & $+8 \%$ & $+8 \%$ & [89] \\
\hline Huperzine A & Alkaloid & Huperzia serrata & ND & $+13 \%$ & & [90] \\
\hline $\begin{array}{l}\text { 10-Hydroxy-2-decenoic } \\
\text { acid }\end{array}$ & Organic acid & Royal jelly & ND & $+12 \%$ & $+21 \%$ & [91] \\
\hline Icariin & $\begin{array}{l}\text { Flavonoid } \\
\text { glycoside }\end{array}$ & $\begin{array}{l}\text { Epimedium brevi- } \\
\text { cornum }\end{array}$ & DAF-16个 & $+21 \%$ & & [92] \\
\hline Icariside II & $\begin{array}{l}\text { Flavonoid } \\
\text { glycoside }\end{array}$ & E. brevicornum & $\begin{array}{l}\text { DAF-16个, HSP- } \\
12.3 \uparrow\end{array}$ & $+31 \%$ & & [92] \\
\hline Isorhamnetin & Flavonoid & Onion & ROS $\downarrow$ & $+16 \%$ & $+16 \%$ & [93] \\
\hline Kaempferol & Flavonoid & Fruits, vegetables & DAF-16个, ROS $\downarrow$ & $\begin{array}{l}+10 \% \\
\text { (heat) }\end{array}$ & $+7 \%$ & {$[80,94]$} \\
\hline Laricitrin & Flavonoid & $\begin{array}{ll}\text { Red grapes and } \\
\text { wine }\end{array}$ & DAF-16个 & $+55 \%$ & & [95] \\
\hline Lignans & Polyphenol & Arctium lappa & DAF-16个 & $+25 \%$ & & [96] \\
\hline Lovastatin & Lactone & Mushrooms & DAF-16个 & $+25 \%$ & & [97] \\
\hline Metformin & Biguanide & $\begin{array}{ll}\text { Anti-diabetic } & \text { drug } \\
\text { (derived } & \text { from } \\
\text { French lilac) } & \end{array}$ & $\begin{array}{l}\text { AAK-2/AMPK } \uparrow, \\
\text { TOR } \downarrow, \quad \text { SKN-1 } \uparrow, \\
\text { methionine } \downarrow, \quad \text { ag- } \\
\text { matine } \uparrow\end{array}$ & $\begin{array}{l}+40 \% \text { (me- } \\
\text { dian) }\end{array}$ & & $\begin{array}{l}{[37,} \\
100]\end{array}$ \\
\hline Monascin & $\begin{array}{l}\text { Azaphilo- } \\
\text { noid }\end{array}$ & $\begin{array}{l}\text { Monascus pur- } \\
\text { pureus }\end{array}$ & $\begin{array}{l}\text { DAF-16个, SOD-1个, } \\
\text { HSP-16.2个 }\end{array}$ & $\begin{array}{l}+29 \% \\
\text { (CL2006 } \\
\text { strain) } \\
\end{array}$ & & {$[101]$} \\
\hline Myricetin & Flavonoid & Fruits, vegetables & $\begin{array}{l}\text { DAF-16个, ROS } \downarrow, \\
\text { Sir-2.1 }\end{array}$ & $+48 \%$ & $+22 \%$ & $\begin{array}{l}{[94,95,} \\
102,103]\end{array}$ \\
\hline Myricetin-trimethylether & Flavonoid & Bridelia plant & DAF-16个 & $+54 \%$ & & [95] \\
\hline Naphthazarin & $\begin{array}{l}\text { Naphtho- } \\
\text { quinone }\end{array}$ & Plants & SKN-1个 & $+13 \%$ & $+25 \%$ & [18] \\
\hline NDGA & Polyphenol & Larrea tridentata & Autophagy $\uparrow$ & $\begin{array}{l}+21 \% \\
\text { (median) }\end{array}$ & & {$[104]$} \\
\hline 5'-Octanoyl salicylic acid & Organic acid & $\begin{array}{l}\text { Skin exfoliating drug } \\
\text { (aspirin derivative) }\end{array}$ & $\begin{array}{l}\text { AAK-2/AMPK } \uparrow, \\
\text { TOR } \downarrow \text {, autophagy } \uparrow, \\
\text { UPR }\end{array}$ & $+19 \%$ & $+12 \%$ & {$[105]$} \\
\hline Oleanolic acid & Terpenoid & Plants & DAF-16个, ROS $\downarrow$ & $+17 \%$ & & [106] \\
\hline Oxoline & $\begin{array}{l}\text { Naphtho- } \\
\text { quinone }\end{array}$ & Plants & ND & $+15 \%$ & $+10 \%$ & {$[18]$} \\
\hline Piceatannol & Stilbenoid & Red grape, wine & $\begin{array}{l}\text { DAF-2, DAF-16个, Sir- } \\
2.1\end{array}$ & $\begin{array}{l}+18 \% \text { (me- } \\
\text { dian) }\end{array}$ & & {$[107]$} \\
\hline Plant extract & Mixture & Alpinia zerumbet & SOD-3个, HSP-16.2个 & $+23 \%$ & $+61 \%$ & {$[108]$} \\
\hline Plant extract & Mixture & $\begin{array}{l}\text { Anacardium occi- } \\
\text { dentale }\end{array}$ & $\begin{array}{l}\text { DAF-16个， SKN-1个， } \\
\text { SOD-3个 }\end{array}$ & $+20 \%$ & & {$[109]$} \\
\hline Plant extract & Mixture & Betula utilis & $\begin{array}{l}\text { DAF-16个, HSF-1个, } \\
\text { SKN-1个, ROS } \downarrow\end{array}$ & $+36 \%$ & & {$[110]$} \\
\hline Plant extract & Mixture & Black tea & ND & ND & & [111] \\
\hline Plant extract & Mixture & $\begin{array}{l}\text { Caesalpinia mimo- } \\
\text { soides }\end{array}$ & DAF-16个, ROS $\downarrow$ & $+4 \%$ & & [112] \\
\hline Plant extract & Mixture & $\begin{array}{l}\text { Damnacanthus } \\
\text { officinarum }\end{array}$ & ND & $+10-30 \%$ & & {$[113]$} \\
\hline Plant extract & Mixture & Dioscorea alata & HSP-16.2个, SKN-1个 & $+28 \%$ & & [114] \\
\hline
\end{tabular}


TABLE 1 (continued). Examples of naturally-occurring substances and related pharmaceutical drugs that extend $C$. elegans lifespan.

\begin{tabular}{|c|c|c|c|c|c|c|}
\hline Substance & $\begin{array}{l}\text { Chemical } \\
\text { Class }\end{array}$ & Source & $\begin{array}{l}\text { Mechanism } \\
\text { (or Gene Involved) }\end{array}$ & $\begin{array}{l}\text { Mean } \\
\text { Lifespan }\end{array}$ & $\begin{array}{l}\text { Maximum } \\
\text { Lifespan }\end{array}$ & Ref. \\
\hline Plant extract & Mixture & $\begin{array}{l}\text { Eleutherococcus } \\
\text { senticosus }\end{array}$ & DAF-16个 & $+16 \%$ & $+12 \%$ & [25] \\
\hline Plant extract & Mixture & Garlic & DAF-16个 & $+21 \%$ & & [115] \\
\hline Plant extract & Mixture & Ginkgo biloba & ROS $\downarrow$ & $\begin{array}{l}+8 \% \\
\text { (median) }\end{array}$ & & {$[116,117]$} \\
\hline Plant extract & Mixture & $\begin{array}{l}\text { Glochidion zeylan- } \\
\text { icum }\end{array}$ & 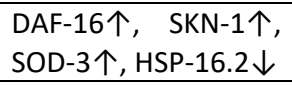 & $+10 \%$ & & {$[118]$} \\
\hline Plant extract & Mixture & Green tea & EAT-2 & ND & & {$[111]$} \\
\hline Plant extract & Mixture & Guarana & DAF-16个 & $+14 \%$ & & {$[119]$} \\
\hline Plant extract & Mixture & Hibiscus sabdariffa & DAF-16个, SKN-1个 & $+24 \%$ & & {$[120]$} \\
\hline Plant extract & Mixture & Lonicera japonica & $\begin{array}{l}\text { DAF-2, DAF-16个, } \\
\text { SOD-3个, ROS } \downarrow\end{array}$ & $+22 \%$ & & {$[121]$} \\
\hline Plant extract & Mixture & Pu-er tea & ND & ND & & {$[111]$} \\
\hline Plant extract & Mixture & Ribes fasciculatum & $\begin{array}{l}\text { DAF-2, AGE-1, DAF- } \\
16 \uparrow, \text { Sir-2.1, SOD个, } \\
\text { ROS } \downarrow\end{array}$ & $+16 \%$ & $+19 \%$ & {$[122]$} \\
\hline Plant extract & Mixture & Rhodiola rosea & DAF-16个 & $+15 \%$ & $+12 \%$ & [25] \\
\hline Plant extract & Mixture & Rooibos tea & HSP-16.2ฟ & $\begin{array}{l}+23 \% \text { (high } \\
\text { glucose } \\
\text { only) }\end{array}$ & & [48] \\
\hline Plant extract & Mixture & $\begin{array}{l}\text { Turkish medicinal } \\
\text { plants }\end{array}$ & ND & $+24 \%$ & & [123] \\
\hline Plant extract & Mixture & $\begin{array}{l}\text { Viscum album col- } \\
\text { oratum }\end{array}$ & Sir2 & $+10 \%$ & & [26] \\
\hline Plumbagin & $\begin{array}{l}\text { Naphtho- } \\
\text { quinone }\end{array}$ & Plumbago zeylanica & DAF-16个，SKN-1个 & $+12 \%$ & $+13 \%$ & {$[18]$} \\
\hline Polydatin & $\begin{array}{l}\text { Stilbenoid } \\
\text { glycoside }\end{array}$ & Grape & DAF-16个, SOD-3个 & $+31 \%$ & & {$[124]$} \\
\hline Polysaccharides & $\begin{array}{l}\text { Polysaccha- } \\
\text { ride }\end{array}$ & A. membranaceus & DAF-16个 & $\begin{array}{l}+20 \% \\
\text { (median) }\end{array}$ & & {$[125]$} \\
\hline Polysaccharides & $\begin{array}{l}\text { Polysaccha- } \\
\text { ride }\end{array}$ & $\begin{array}{l}\text { Auricularia auricu- } \\
\text { lar }\end{array}$ & $\begin{array}{l}\text { DAF-16个， SKN-1个, } \\
\text { Sir-2.1 }\end{array}$ & $-18 \%$ & $+22 \%$ & {$[126]$} \\
\hline Polysaccharides & $\begin{array}{l}\text { Polysaccha- } \\
\text { ride }\end{array}$ & $\begin{array}{l}\text { Chlorophytum } \\
\text { borivilianum }\end{array}$ & ND & $\begin{array}{l}+23 \% \\
\text { (median) }\end{array}$ & & {$[127]$} \\
\hline Polysaccharides & $\begin{array}{l}\text { Polysaccha- } \\
\text { ride }\end{array}$ & Cordyceps militaris & ND & $+17 \%$ & & {$[128]$} \\
\hline $\begin{array}{l}\text { Polysaccharides } \\
\text { (lentinan) }\end{array}$ & $\begin{array}{l}\text { Polysaccha- } \\
\text { ride }\end{array}$ & Lentinula edodes & ND & $+11 \%$ & & {$[128]$} \\
\hline Polysaccharides & $\begin{array}{l}\text { Polysaccha- } \\
\text { ride }\end{array}$ & Panax notoginseng & $\begin{array}{l}\text { SOD } \uparrow, \quad \text { catalase } \uparrow, \\
\text { MDA } \downarrow\end{array}$ & $+21 \%$ & & [129] \\
\hline Polysaccharides & $\begin{array}{l}\text { Polysaccha- } \\
\text { ride }\end{array}$ & G. lucidum & $\begin{array}{l}\text { DAF-16个, autopha- } \\
\text { gy }\end{array}$ & $\begin{array}{l}+44 \% \\
\text { (median) }\end{array}$ & & $\begin{array}{l}\text { [130], } \\
\text { un- } \\
\text { published } \\
\text { data }\end{array}$ \\
\hline Polysaccharides & $\begin{array}{l}\text { Polysaccha- } \\
\text { ride }\end{array}$ & $\begin{array}{l}\text { Rehmannia glutino- } \\
\text { sa }\end{array}$ & DAF-16个 & ND & & [131] \\
\hline Polyphenols & Polyphenol & Apple & Sir-2.1 & $+12 \%$ & & {$[132]$} \\
\hline Polyphenols & Polyphenol & Blueberry & $\begin{array}{l}\text { ROS } \downarrow, \text { OSR-1, SEK- } \\
1 \uparrow\end{array}$ & $+28 \%$ & $+14 \%$ & [133] \\
\hline Polyphenols & Polyphenol & Cocoa & DAF-16个, Sir-2.1 & $\begin{array}{l}+17 \% \text { (me- } \\
\text { dian) }\end{array}$ & & {$[134]$} \\
\hline Quercetin & Flavonoid & Vegetables & $\begin{array}{l}\text { AGE-1, DAF-2, DAF- } \\
16 \uparrow, \text { SEK-1个 }\end{array}$ & $+15 \%$ & $+18 \%$ & $\begin{array}{l}54, \\
93,94 \\
135-138]\end{array}$ \\
\hline Quercetin-3-O-glucoside & $\begin{array}{l}\text { Flavonoid } \\
\text { glycoside }\end{array}$ & Vegetables & ND & $+23 \%$ & $+7 \%$ & {$[139]$} \\
\hline Quinic acid & Polyol & Uncaria tomentosa & DAF-16个, SOD-3个 & $+7 \%$ & & {$[140]$} \\
\hline
\end{tabular}


TABLE 1 (continued). Examples of naturally-occurring substances and related pharmaceutical drugs that extend C. elegans lifespan.

\begin{tabular}{|c|c|c|c|c|c|c|}
\hline Substance & $\begin{array}{l}\text { Chemical } \\
\text { Class }\end{array}$ & Source & $\begin{array}{l}\text { Mechanism } \\
\text { (or Gene Involved) }\end{array}$ & $\begin{array}{l}\text { Mean } \\
\text { Lifespan }\end{array}$ & $\begin{array}{l}\text { Maximum } \\
\text { Lifespan }\end{array}$ & Ref. \\
\hline Reserpine & Alkaloid & $\begin{array}{l}\text { Indian snakeroot, } \\
\text { anti-hypertensive } \\
\text { drug }\end{array}$ & Stress tolerance $\uparrow$ & $+31 \%$ & & [141] \\
\hline Resveratrol & Stilbenoid & $\begin{array}{l}\text { Red wine, dietary } \\
\text { supplement }\end{array}$ & Sir-2.1, autophagy $\uparrow$ & $+18 \%$ & & [142-147] \\
\hline Rosmarinic acid & Polyphenol & R. officinalis & $\begin{array}{l}\text { DAF-16个, OSR-1, } \\
\text { SEK-1个, Sir-2.1 }\end{array}$ & $+63 \%$ & & {$[54,148]$} \\
\hline Royal jelly & Mixture & $\begin{array}{l}\text { Dietary supple- } \\
\text { ment }\end{array}$ & DAF-16个 & $+9 \%$ & & [91] \\
\hline S-allylcysteine & $\begin{array}{l}\text { Organosul- } \\
\text { fur }\end{array}$ & Garlic & SKN-1个 & $+17 \%$ & & [149] \\
\hline S-allylmercaptocysteine & $\begin{array}{l}\text { Organosul- } \\
\text { fur }\end{array}$ & Garlic & SKN-1个 & $+21 \%$ & & [149] \\
\hline Spermidine & Polyamine & Natto, mushrooms & Autophagy $\uparrow$ & $+15 \%$ & & [150] \\
\hline Silymarin & $\begin{array}{l}\text { Flavo- } \\
\text { nolignan }\end{array}$ & Milk thistle & $\begin{array}{l}\text { DAF-16个, SOD-3个, } \\
\text { ROS } \downarrow\end{array}$ & $+18 \%$ & & [151] \\
\hline Simvastatin & Lactone & $\begin{array}{l}\text { Cholesterol- } \\
\text { lowering drug (de- } \\
\text { rived from fungi) }\end{array}$ & ND & $+13 \%$ & & [97] \\
\hline Syringetin & Flavonoid & Sichuan pepper & DAF-16个 & $+36 \%$ & & [95] \\
\hline Tamarixetin & Flavonoid & G. biloba & ROS $\downarrow$ & $\begin{array}{l}+29 \% \\
\text { (median) }\end{array}$ & & {$[93,116]$} \\
\hline Tambulin & Flavonoid & $\begin{array}{l}\text { Zanthoxyllum ar- } \\
\text { amatum }\end{array}$ & $\begin{array}{l}\text { DAF-16个, SOD-1个, } \\
\text { SOD-3个, ROS } \downarrow\end{array}$ & $+17 \%$ & & [152] \\
\hline Tannic acid & Polyphenol & Plants & SEK-1个 & $+19 \%$ & & {$[62,153]$} \\
\hline Taurine & $\begin{array}{l}\text { Amino sul- } \\
\text { fonic acid }\end{array}$ & $\begin{array}{l}\text { Dietary supple- } \\
\text { ment }\end{array}$ & ND & $+11 \%$ & & {$[154]$} \\
\hline Theanine & Amino acid & $\begin{array}{l}\text { Tea, dietary sup- } \\
\text { plement }\end{array}$ & ND & $+14 \%$ & & {$[154,155]$} \\
\hline Theophylline & Alkaloid & Coffee & ROS $\downarrow$ & $+21 \%$ & & [19] \\
\hline Tocotrienols & Tocopherol & Fruits, vegetables & ROS $\downarrow$ & $+20 \%$ & & [156] \\
\hline Tomatidine & Alkaloid & Unripe tomatoe & SKN-1个 & $+7 \%$ & & [157] \\
\hline Trehalose & $\begin{array}{l}\text { Disaccha- } \\
\text { ride }\end{array}$ & $\begin{array}{l}\text { Vegetables, mush- } \\
\text { rooms }\end{array}$ & DAF-2 & $+30 \%$ & & [158] \\
\hline Triptolide & Terpenoid & T. wilfordii & $\begin{array}{ll}\text { SOD-3个, } & \text { HSP- } \\
16.2 \uparrow, R O S \downarrow & \end{array}$ & $+20 \%$ & $+16 \%$ & [159] \\
\hline Ursolic acid & Terpenoid & Plants & SKN-1个 & $+31 \%$ & & [160] \\
\hline
\end{tabular}

The "Mechanism" column displays modulation of specific cellular components (e.g., DAF-16个, SOD-1个, ROS $\downarrow$ ) or involvement of particular genes, proteins and enzymes (e.g., DAF-2, OSR-1, Sir-2.1). In the "Lifespan" column, the parentheses indicate that lifespan assays were performed in the presence of cellular stress such as high glucose, heat or paraquat; in some studies, extension of "median" lifespan was reported. Only the highest increase in mean, median or maximum lifespan is shown. Abbreviations: AAK-2, 5' adenosine-monophosphateactivated protein kinase catalytic subunit alpha 2; AGE-1, phosphatidylinositol 3-kinase age 1; AGEs, advanced glycation endproducts; AMPK, 5'-adenosine-monophosphate-activated protein kinase; CBP-1, calcineurin-binding protein-1; DAF, abnormal dauer formation protein; EGCG, epigallocatechin gallate; FOX, forkhead box; GLP-1, abnormal germ line proliferation; HSF-1, heat shock factor 1; HSP, heatshock protein; MDA, malondialdehyde; ND, not determined; NDGA, nordihydroguaiaretic acid; OSR-1, odd-skipped-related protein-1; ROS, reactive oxygen species; Sir, sirtuin; SKN-1, skinhead protein 1; SOD, superoxide dismutase; TOR, target of rapamycin; UPR ${ }^{\text {mit, }}$ mitochondrial unfolded protein response.

However, several lines of evidence indicate that these molecules may act in other ways, notably by inducing stress resistance and anti-aging pathways $[5,6]$. Accordingly, the antioxidant properties of phytochemicals in vitro do not correlate with anti-aging effects in C. elegans [17]. Moreover, some phytochemicals can, instead, extend $C$. elegans lifespan by inducing ROS formation, which in turn leads to expression of SKN-1 and antioxidant enzymes that protect from oxidative stress by inactivating ROS [18]. For example, theophylline, a methylxanthine compound found in cocoa, chocolate, tea and guarana, slightly increases ROS levels in C. elegans, which prolongs lifespan and increases resistance to the ROS-producer juglone [19]. Plant molecules that induce ROS formation may activate c-Jun N-terminal kinase 1 (JNK-1) and DAF-16 (Figure 2). Other phytochemicals acti- 
vate $\mathrm{SKN}-1$ and lead to reduction of ROS in a similar manner (Table 1).

While several plant-derived compounds extend lifespan in nematodes, conflicting results have been obtained in some cases, possibly due to differences in study design or experimental conditions. For instance, the Caenorhabditis Intervention Testing Program, which aims to identify antiaging compounds that prolong lifespan in genetically diverse cohorts of $C$. elegans, reported that aspirin does not extend lifespan [20], contradicting the results of previous studies [21, 22].

\section{LIFESPAN EXTENSION OCCURS VIA HORMESIS}

It has been proposed that many molecules derived from plants and fungi induce stress resistance and defense mechanisms via hormesis, i.e., which posits that cellular stress that is detrimental at high intensity can produce health benefits at low intensity $[5,6,23]$. By activating autophagy, mitochondrial biogenesis and expression of antioxidant and detoxifying enzymes, plant and fungal products reduce cellular damage and improve cellular functions, thus reducing aging and extending longevity [6]. This mechanism is consistent with the concept that, under conditions of stress such as CR, the organism allocates more energy for resistance and survival, instead of growth and reproduction [24].

The hormetic dose-dependence is observed in several studies listed in Table 1. For example, treatment of $C$. elegans with an extract of Siberian ginseng (Eleutherococcus senticosus) extends mean lifespan by $5 \%$ at low dose $(100 \mu \mathrm{g} / \mathrm{ml})$ and by $16 \%$ at intermediate dose $(250 \mu \mathrm{g} / \mathrm{ml})$, whereas the same extract reduces mean lifespan by $23 \%$ at high dose $(2,500 \mu \mathrm{g} / \mathrm{ml})$ [25]. Similar hormetic doseresponses involving lifespan extension at low doses and

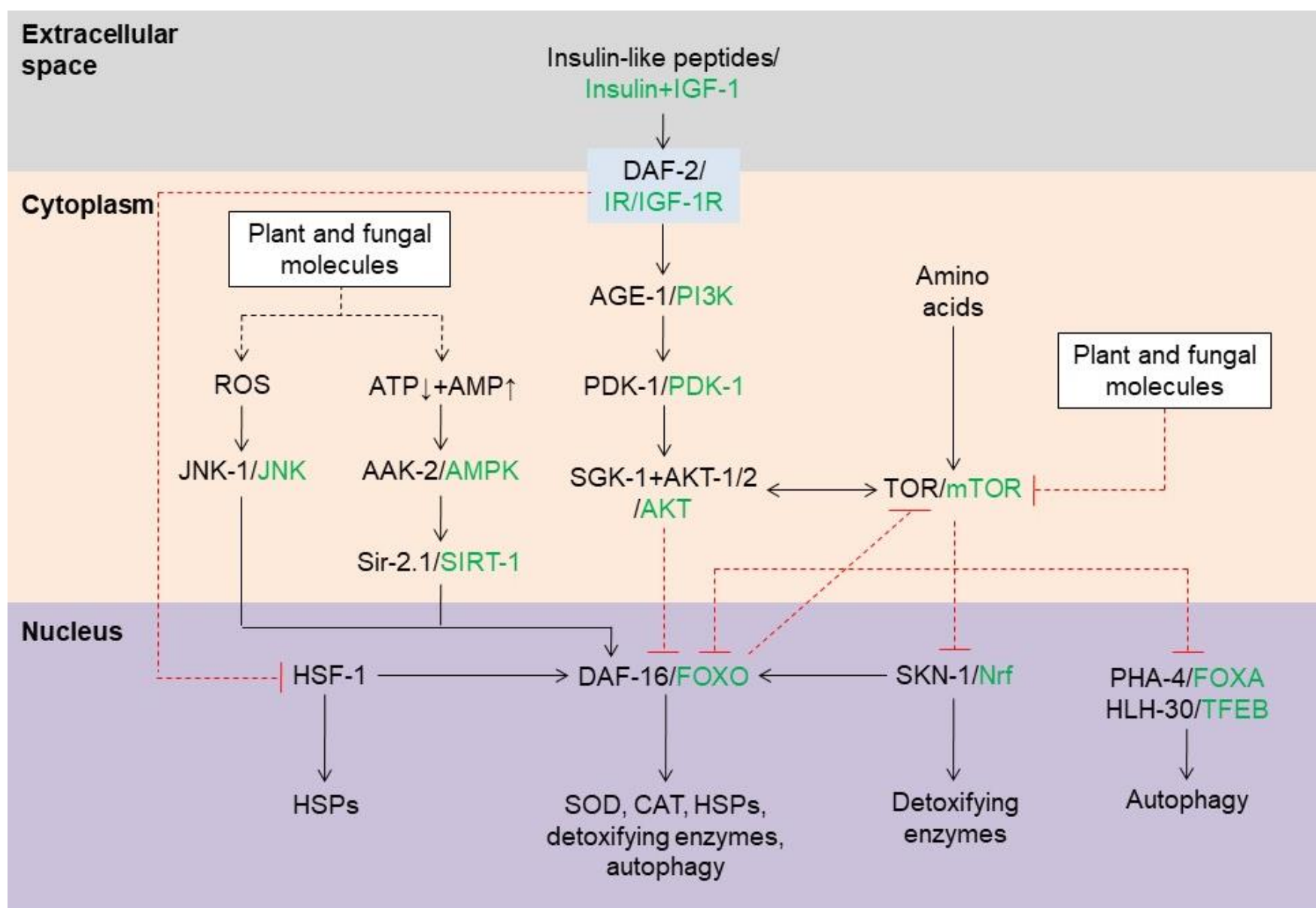

FIGURE 2: Aging-related pathways modulated by plant and fungal molecules in $\boldsymbol{C}$. elegans. Plant and fungal molecules extend nematode lifespan by inducing the formation of ROS, by activating AAK-2/AMPK, or by inhibiting the insulin or TOR pathway. General cellular pathways are shown here, but variations may occur between cells of different tissues. Human protein homologs are given in green. Abbreviations: AGE-1, phosphatidylinositol 3-kinase age 1; AMP, adenosine monophosphate; ATP, adenosine triphosphate; AAK-2, 5' adenosine-monophosphateactivated protein kinase catalytic subunit alpha 2; AMPK, $5^{\prime}$ adenosine-monophosphate-activated protein kinase; CAT, catalase; DAF, abnormal dauer formation protein; FOX, forkhead box; HLH-30, basic helix-loop-helix protein 30; HSF-1, heat-shock factor 1; HSPs, heat-shock proteins; IGF-1, insulin-like growth factor 1; IGF-1R, insulin-like growth factor 1 receptor; IR, insulin receptor; JNK, c-Jun N-terminal kinase; mTOR, mammalian target of rapamycin; Nrf, nuclear factor erythroid 2-related factor; PDK-1, 3' phosphoinositide-dependent protein kinase 1; PHA-4, defective pharyngeal development protein 4; PI3K, phosphoinositide 3-kinase; ROS, reactive oxygen species; SGK-1, serum and glucocorticoidregulated kinase-1; Sir-2.1, sirtuin 2.1; SIRT-1, sirtuin 1; SKN-1, skinhead 1; SOD, superoxide dismutase; TFEB, HLH transcription factor EB; TOR, target of rapamycin. 
lifespan shortening at high doses were obtained for plant extracts of Rhodiola rosea [25] and mistletoe [26], and for the tea polyphenol epigallocatechin gallate (EGCG) [27], to name a few. However, this dose dependence has been largely overlooked in many studies, while in other cases, a relatively narrow range of concentrations tested may have prevented the observation of hormetic dose-responses.

Another observation suggesting that plant and fungal compounds extend lifespan via hormesis is the fact that stress resistance pathways are activated in the treated worms. Thus, many plant and fungal compounds that include 4,4'-dimethoxychalcone, glucosamine, nordihydroguaiaretic acid (NDGA), resveratrol and spermidine extend the lifespan of $C$. elegans by activating autophagy (Table 1 and Figure 2), which in itself is a typical cellular response to stress $[6,28]$. We also observed that polysaccharides isolated from the medicinal fungus $G$. lucidum extend the lifespan of $C$. elegans by inducing autophagy (unpublished data). In addition, several plant and fungal products increase the levels of HSPs and antioxidant and detoxifying enzymes (Table 1), reflecting a cellular response that aims to maintain homeostasis in response to stress.

Plant and fungal compounds can also induce mitochondrial biogenesis via a process referred to as "mitohormesis" [29]. High levels of ROS usually induce cellular damage, but as mentioned above some phytochemicals can induce the formation of low levels of ROS which in turn induce stress resistance mechanisms. In this case, cells respond by forming new mitochondria which in turn may improve cellular function and longevity. Examples of natural compounds that act this way in nematodes include EGCG [27] and glucosamine [30] (Table 1). Of note, excess intake of antioxidants such as vitamins $C$ and $E$ may reduce the health benefits of anti-aging interventions like exercise in humans by preventing mitohormesis [29].

In the studies consulted, plant and fungal extracts and molecules extend mean or median lifespan of nematodes by an average of 4 to $63 \%$ (Table 1). These lifespan extensions are consistent with the hormetic effects observed in a large number of studies reporting the responses of microbes, plants and animals to various forms of biological stress, in which maximum effects of $20-90 \%$ above control were reported [31]. While hormetic responses may be relatively modest in magnitude, they are nevertheless highly significant in view of their overall impact on health and longevity.

Of note, only some plant or fungal substances increase maximum lifespan, producing increases ranging from 7 to $68 \%$ (Table 1). While a description of the effects on maximum lifespan may have been omitted in some studies, this observation nonetheless suggests that the treatments may reduce the number of deaths in adult worms at some point in time but fail to extend the lifespan of old worms. Given that hormetic effects have been attributed to an overcompensation of homeostasis-regulating mechanisms and may thus rely on the capacity to maintain homeostasis [32], the absence of effects on maximum lifespan in some studies may indicate that very old individuals are unable to maintain homeostasis in response to biological stress, possibly due to a loss of resilience. Consistent with this possibility, feeding $C$. elegans with metformin late in life produces toxic effects and reduces lifespan by exacerbating agerelated mitochondrial dysfunction [33], unlike the lifespanenhancing effects of metformin seen in younger worms. Similarly, the lifespan-extension effects of EGCG decline with age [27]. This indicates that CR mimetics-and possibly other anti-aging interventions that work through hormesis-may be ineffective and even detrimental in very old individuals.

\section{EFFECTS OF NATURAL PRODUCTS ON HEALTHSPAN VIA THE GUT MICROBIOTA}

While studies in $C$. elegans have focused on extension of lifespan, many reports showed that natural substances that extend lifespan also produce beneficial effects on healthspan. For instance, plant-derived polyphenols such as chlorogenic acid, which is found in vegetables and coffee, improve insulin sensitivity and mobility in the treated worms [34]. Similarly, carnosic acid, a diterpene compound isolated from rosemary (Rosmarinus officinalis), improves mobility and aging-related pigmentation and neurodegeneration in nematodes [35]. These observations are consistent with the view that interventions that prolong lifespan may also improve physiological functions and reduce development of chronic disease.

Recent studies suggest that some of the beneficial effects on health and longevity in nematodes may take place via modulation of the gut microbiota. A key study showed that Escherichia coli mutants deficient in some biochemical components can extend nematode lifespan [36]. This study reported that production of the polysaccharide colanic acid by gut bacteria can extend lifespan and reduce age-related pathologies by inducing the unfolded protein response in the host. Similarly, metformin can extend lifespan and regulate host lipid metabolism via production of the metabolite agmatine by the gut microbiota [37]. Other studies showed that a strain of the probiotic Lactobacillus rhamnosus [38] or Weissella bacteria activated the DAF-16 pathway and extended $C$. elegans lifespan compared to feeding with E. coli [39]. However, these results may also be partially explained by the observation that $E$. coli becomes pathogenic for old worms and feeding with less pathogenic bacteria may therefore extend nematode lifespan [40]. Given that major differences exist between gut microbiota composition in C. elegans and humans-including the fact that the gut microbiota in nematodes studied in vitro usually consists of a single bacterial species provided as foodfurther studies are needed to assess the relevance of these observations in humans.

\section{CHALLENGES AND OPPORTUNITIES}

Our overview indicates that many plant and fruit extracts derived from blueberries to garlic, as well as plant molecules such as chlorophyll and caffeine, extend the lifespan of $C$. elegans (Table 1). Yet, many factors may partially limit the relevance of these findings for humans, including major differences in physiology and metabolism. Health and lon- 
gevity in humans depend on complex interactions between genetic background, lifestyle and diet, which can hardly be reproduced in experimental settings. It is likely that common lifestyle habits such as overeating, smoking, sedentarity, alcohol intake, stress and poor sleep, as well as environmental factors such as pollution, ultraviolet light and toxins, may reduce, suppress or even reverse the beneficial effects of phytochemicals and CR mimetics on health and longevity. Moreover, the appropriate concentrations and treatment schedule required to produce optimal health benefits remains largely unknown. The observations reported here also suggest that $C R$ mimetics may become ineffective and even detrimental at very old age, therefore requiring the identification of optimal doses for older individuals and the development of new ways to monitor homeostasis and resilience.

Nonetheless, several epidemiological studies suggest that some of the plant-derived molecules described here may reduce human mortality and chronic diseases in humans. For instance, individuals who regularly consume coffee-arguably the highest source of polyphenols and caffeine in the human diet-live longer and show a reduced incidence of cancer, cardiovascular disease and Alzheimer's disease compared with non-consumers [41, 42]. Similarly, people who regularly take metformin [43] or glucosamine [44, 45], as well as those who have a higher dietary intake of spermidine [46], live longer than nonusers or controls. Finally, many CR mimetics derived from natural sources and studied in $C$. elegans, including quercetin, resveratrol and spermidine, have shown promising results in clinical trials [8]. It thus becomes a matter of

\section{REFERENCES}

1. Martins R, Lithgow GJ, Link W (2016). Long live FOXO: unraveling the role of FOXO proteins in aging and longevity. Aging Cell 15(2): 196-207. doi: 10.1111/acel.12427

2. Fontana L, Partridge L, Longo VD (2010). Extending healthy life span-from yeast to humans. Science 328(5976): 321-326. doi: 10.1126/science.1172539

3. Levine ME, Suarez JA, Brandhorst S, Balasubramanian P, Cheng CW, Madia F, Fontana L, Mirisola MG, Guevara-Aguirre J, Wan J, Passarino G, Kennedy BK, Wei M, Cohen P, Crimmins EM, Longo VD (2014). Low protein intake is associated with a major reduction in IGF-1, cancer, and overall mortality in the 65 and younger but not older population. Cell Metab 19(3): 407-417. doi: 10.1016/j.cmet.2014.02.006

4. Solon-Biet SM, McMahon AC, Ballard JW, Ruohonen K, Wu LE, Cogger VC, Warren A, Huang X, Pichaud N, Melvin RG, Gokarn R, Khalil M, Turner N, Cooney GJ, Sinclair DA, Raubenheimer D, Le Couteur DG, Simpson SJ (2014). The ratio of macronutrients, not caloric intake, dictates cardiometabolic health, aging, and longevity in ad libitum-fed mice. Cell Metab 19(3): 418-430. doi: 10.1016/j.cmet.2014.02.009

5. Son TG, Camandola S, Mattson MP (2008). Hormetic dietary phytochemicals. Neuromolecular Med 10(4): 236-246. doi: 10.1007/s12017-008-8037-y

6. Martel J, Ojcius DM, Ko YF, Ke PY, Wu CY, Peng HH, Young JD (2019) Hormetic effects of phytochemicals on health and longevity. Trends Endocrinol Metab 30(6): 335-346. doi: 10.1016/j.tem.2019.04.001 when and how-as opposed to if-these plant and fungal molecules can be used in humans.

\section{ACKNOWLEDGMENTS}

We thank Dr. Szecheng J. Lo at Chang Gung University for helpful discussions and for providing reagents to study the effects of natural products in C. elegans. The authors' work is supported by Primordia Institute of New Sciences and Medicine, by grant MOST 109-2311-B-182-001-MY2 from Taiwan's Ministry of Science and Technology, and grant NMRPD1K0031 from Chang Gung University.

\section{CONFLICT OF INTEREST}

Y-F.K. is president of Chang Gung Biotechnology. J.D.Y. is Chairman of the Board of Chang Gung Biotechnology. The authors have filed patents related to the preparation and use of dietary supplements and probiotics.

\section{COPYRIGHT}

(C) 2020 Martel et al. This is an open-access article released under the terms of the Creative Commons Attribution (CC BY) license, which allows the unrestricted use, distribution, and reproduction in any medium, provided the original author and source are acknowledged.

Please cite this article as: Jan Martel, Cheng-Yeu Wu, Hsin-Hsin Peng, Yun-Fei Ko, Hung-Chi Yang, John D. Young and David M. Ojcius (2020). Plant and fungal products that extend lifespan in Caenorhabditis elegans. Microbial Cell 7(10): 255-269. doi: 10.15698/mic2020.10.731

7. Ruby JG, Wright KM, Rand KA, Kermany A, Noto K, Curtis D, Varner N, Garrigan D, Slinkov D, Dorfman I, Granka JM, Byrnes J, Myres N, Ball $C$ (2018). Estimates of the heritability of human longevity are substantially inflated due to assortative mating. Genetics 210(3): 1109-1124. doi: 10.1534/genetics.118.301613

8. Madeo F, Carmona-Gutierrez D, Hofer SJ, Kroemer G (2019). Caloric restriction mimetics against age-associated disease: targets, mechanisms, and therapeutic potential. Cell Metab 29(3): 592-610. doi: 10.1016/j.cmet.2019.01.018

9. Lee J, Jo DG, Park D, Chung HY, Mattson MP (2014). Adaptive cellular stress pathways as therapeutic targets of dietary phytochemicals: focus on the nervous system. Pharmacol Rev 66(3): 815-868. doi: 10.1124/pr.113.007757

10. Martel J, Ojcius DM, Ko YF, Chang CJ, Young JD (2019). Antiaging effects of bioactive molecules isolated from plants and fungi. Med Res Rev 39(5): 1515-1552. doi: 10.1002/med.21559

11. Tissenbaum HA (2015). Using C. elegans for aging research. Invertebr Reprod Dev 59(sup1): 59-63. doi: 10.1080/07924259.2014.940470

12. Lapierre LR, Hansen M (2012). Lessons from C. elegans: signaling pathways for longevity. Trends Endocrinol Metab 23(12): 637-644. doi: 10.1016/j.tem.2012.07.007

13. Kim DH (2013). Bacteria and the aging and longevity of Caenorhabditis elegans. Annu Rev Genet 47: 233-246. doi: 10.1146/annurev-genet-111212-133352 
14. Khan F, Jain S, Oloketuyi SF (2018). Bacteria and bacterial products: Foe and friends to Caenorhabditis elegans. Microbiol Res 215: 102-113. doi: 10.1016/j.micres.2018.06.012

15. Uno $M$, Nishida $E$ (2016). Lifespan-regulating genes in C. elegans. NPJ Aging Mech Dis 2(2): 16010. doi: 10.1038/npjamd.2016.10

16. Lapierre LR, De Magalhaes Filho CD, McQuary PR, Chu CC, Visvikis O, Chang JT, Gelino S, Ong B, Davis AE, Irazoqui JE, Dillin A, Hansen M (2013). The TFEB orthologue HLH-30 regulates autophagy and modulates longevity in Caenorhabditis elegans. Nat Commun 4: 2267. doi: 10.1038/ncomms3267

17. Xue YL, Ahiko T, Miyakawa T, Amino H, Hu F, Furihata K, Kita K, Shirasawa T, Sawano $Y$, Tanokura M (2011). Isolation and Caenorhabditis elegans lifespan assay of flavonoids from onion. J Agric Food Chem 59(11): 5927-5934. doi: 10.1021/jf104798n

18. Hunt PR, Son TG, Wilson MA, Yu QS, Wood WH, Zhang Y, Becker KG, Greig NH, Mattson MP, Camandola S, Wolkow CA (2011). Extension of lifespan in $C$. elegans by naphthoquinones that act through stress hormesis mechanisms. PLoS ONE 6(7): e21922. doi: 10.1371/journal.pone.0021922

19. Li H, Roxo M, Cheng X, Zhang S, Cheng H, Wink M (2019). Prooxidant and lifespan extension effects of caffeine and related methylxanthines in Caenorhabditis elegans. Food Chem X 1: 100005. doi: 10.1016/j.fochx.2019.100005

20. Lucanic M, Plummer WT, Chen E, Harke J, Foulger AC, Onken B, Coleman-Hulbert AL, Dumas KJ, Guo S, Johnson E, Bhaumik D, Xue J, Crist $A B$, Presley MP, Harinath $G$, Sedore $C A$, Chamoli $M$, Kamat $S$, Chen MK, Angeli S, Chang C, Willis JH, Edgar D, Royal MA, Chao EA, Patel S, Garrett T, Ibanez-Ventoso C, Hope J, Kish JL, et al. (2017). Impact of genetic background and experimental reproducibility on identifying chemical compounds with robust longevity effects. Nat Commun 8: 14256. doi: 10.1038/ncomms14256

21. Wan QL, Zheng SQ, Wu GS, Luo HR (2013). Aspirin extends the lifespan of Caenorhabditis elegans via AMPK and DAF-16/FOXO in dietary restriction pathway. Exp Gerontol 48(5): 499-506. doi: 10.1016/j.exger.2013.02.020

22. Ayyadevara S, Bharill P, Dandapat A, Hu C, Khaidakov M, Mitra S, Shmookler Reis RJ, Mehta JL (2013). Aspirin inhibits oxidant stress, reduces age-associated functional declines, and extends lifespan of Caenorhabditis elegans. Antioxid Redox Signal 18(5): 481-490. doi: 10.1089/ars.2011.4151

23. Calabrese V, Cornelius C, Dinkova-Kostova AT, lavicoli I, Di Paola R, Koverech A, Cuzzocrea S, Rizzarelli E, Calabrese EJ (2012). Cellular stress responses, hormetic phytochemicals and vitagenes in aging and longevity. Biochim Biophys Acta 1822(5): 753-783. doi: 10.1016/j.bbadis.2011.11.002

24. Kirkwood TL, Kapahi P, Shanley DP (2000). Evolution, stress, and longevity. J Anat $197 \mathrm{Pt}$ 4: 587-590. doi: 10.1046/j.14697580.2000.19740587.x

25. Wiegant FA, Surinova S, Ytsma E, Langelaar-Makkinje M, Wikman $\mathrm{G}$, Post JA (2009). Plant adaptogens increase lifespan and stress resistance in $C$. elegans. Biogerontology 10(1): 27-42. doi: 10.1007/s10522-008-9151-9

26. Lee SH, An HS, Jung YW, Lee EJ, Lee HY, Choi ES, An SW, Son H, Lee SJ, Kim JB, Min KJ (2014). Korean mistletoe (Viscum album coloratum) extract extends the lifespan of nematodes and fruit flies. Biogerontology 15(2): 153-164. doi: 10.1007/s10522-013-9487-7

27. Xiong LG, Chen YJ, Tong JW, Gong YS, Huang JA, Liu ZH (2018). Epigallocatechin-3-gallate promotes healthy lifespan through mitohormesis during early-to-mid adulthood in Caenorhabditis elegans. Redox Biol 14: 305-315. doi: 10.1016/j.redox.2017.09.019
28. Martel J, Ojcius DM, Ko YF, Young JD (2020). Phytochemicals as prebiotics and biological stress inducers. Trends Biochem Sci 45(6) 462-471. doi: 10.1016/j.tibs.2020.02.008

29. Ristow M, Schmeisser K (2014). Mitohormesis: promoting health and lifespan by increased levels of reactive oxygen species (ROS). Dose Response 12(2): 288-341. doi: 10.2203/dose-response.13035. Ristow

30. Weimer S, Priebs J, Kuhlow D, Groth M, Priebe S, Mansfeld J, Merry TL, Dubuis S, Laube B, Pfeiffer AF, Schulz TJ, Guthke R, Platzer M, Zamboni N, Zarse K, Ristow M (2014). D-Glucosamine supplementation extends life span of nematodes and of ageing mice. Nat Commun 5: 3563. doi: 10.1038/ncomms4563

31. Calabrese EJ, Agathokleous E, Kozumbo WJ, Stanek EJ, 3rd, Leonard D (2019). Estimating the range of the maximum hormetic stimulatory response. Environ Res 170: 337-343. doi: 10.1016/j.envres.2018.12.020

32. Calabrese EJ (2001). Overcompensation stimulation: a mechanism for hormetic effects. Crit Rev Toxicol 31: 425-470. doi: 10.1080/20014091111749

33. Espada L, Dakhovnik A, Chaudhari P, Martirosyan A, Miek L, Poliezhaieva T, Schaub Y, Nair A, Döring N, Rahnis N, Werz O, Koeberle A, Kirkpatrick J, Ori A, Ermolaeva MA (2019). Late life metformin treatment limits cell survival and shortens lifespan by triggering an aging-associated failure of energy metabolism. bioRxiv. doi: doi.org/10.1101/863357

34. Zheng SQ, Huang XB, Xing TK, Ding AJ, Wu GS, Luo HR (2017). Chlorogenic acid extends the lifespan of Caenorhabditis elegans via insulin/IGF-1 signaling pathway. J Gerontol A Biol Sci Med Sci 72(4): 464-472. doi: 10.1093/gerona/glw105

35. Lin C, Zhang X, Su Z, Xiao J, Lv M, Cao Y, Chen Y (2019). Carnosol improved lifespan and healthspan by promoting antioxidant capacity in Caenorhabditis elegans. Oxid Med Cell Longev 2019: 5958043. doi: $10.1155 / 2019 / 5958043$

36. Han B, Sivaramakrishnan P, Lin CJ, Neve IAA, He J, Tay LWR, Sowa JN, Sizovs A, Du G, Wang J, Herman C, Wang MC (2017). Microbial genetic composition tunes host longevity. Cell 169(7): 1249-1262. doi: 10.1016/j.cell.2017.05.036

37. Pryor R, Norvaisas $P$, Marinos $G$, Best $L$, Thingholm LB, Quintaneiro LM, De Haes W, Esser D, Waschina S, Lujan C, Smith RL, Scott TA, Martinez-Martinez D, Woodward O, Bryson K, Laudes M, Lieb W, Houtkooper RH, Franke A, Temmerman L, Bjedov I, Cocheme HM, Kaleta C, Cabreiro F (2019). Host-microbe-drug-nutrient screen identifies bacterial effectors of metformin therapy. Cell 178(6): 12991312. doi: 10.1016/j.cell.2019.08.003

38. Grompone G, Martorell P, Llopis S, Gonzalez N, Genoves S, Mulet AP, Fernandez-Calero T, Tiscornia I, Bollati-Fogolin M, Chambaud I, Foligne B, Montserrat A, Ramon D (2012). Anti-inflammatory Lactobacillus rhamnosus CNCM $\mathrm{I}-3690$ strain protects against oxidative stress and increases lifespan in Caenorhabditis elegans. PLoS ONE 7(12): e52493. doi: 10.1371/journal.pone.0052493

39. Lee J, Kwon G, Lim YH (2015). Elucidating the mechanism of Weissella-dependent lifespan extension in Caenorhabditis elegans. Sci Rep 5: 17128. doi: 10.1038/srep17128

40. Collins JJ, Evason K, Kornfeld K (2006). Pharmacology of delayed aging and extended lifespan of Caenorhabditis elegans. Exp Gerontol 41(10): 1032-1039. doi: 10.1016/j.exger.2006.06.038

41. Freedman ND, Park Y, Abnet CC, Hollenbeck AR, Sinha R (2012). Association of coffee drinking with total and cause-specific mortality N Engl J Med 366(20): 1891-1904. doi: 10.1056/NEJMoa1112010

42. Takahashi K, Ishigami A (2017). Anti-aging effects of coffee. Aging 9(8): 1863-1864. doi: 10.18632/aging.101287 
43. Bannister CA, Holden SE, Jenkins-Jones S, Morgan CL, Halcox JP, Schernthaner G, Mukherjee J, Currie CJ (2014). Can people with type 2 diabetes live longer than those without? A comparison of mortality in people initiated with metformin or sulphonylurea monotherapy and matched, non-diabetic controls. Diabetes Obes Metab 16(11): 11651173. doi: 10.1111/dom.12354

44. Pocobelli G, Kristal AR, Patterson RE, Potter JD, Lampe JW, Kolar A, Evans I, White E (2010). Total mortality risk in relation to use of lesscommon dietary supplements. Am J Clin Nutr 91(6): 1791-1800. doi: 10.3945/ajcn.2009.28639

45. Bell GA, Kantor ED, Lampe JW, Shen DD, White E (2012). Use of glucosamine and chondroitin in relation to mortality. Eur J Epidemiol 27(8): 593-603. doi: 10.1007/s10654-012-9714-6

46. Kiechl S, Pechlaner R, Willeit P, Notdurfter M, Paulweber B, Willeit K, Werner $\mathrm{P}$, Ruckenstuhl C, Iglseder B, Weger S, Mairhofer B, Gartner M, Kedenko L, Chmelikova M, Stekovic S, Stuppner H, Oberhollenzer F, Kroemer G, Mayr M, Eisenberg T, Tilg H, Madeo F, Willeit J (2018). Higher spermidine intake is linked to lower mortality: a prospective population-based study. Am J Clin Nutr 108: 371-380. doi: 10.1093/ajcn/nqy102

47. Senthil KK, Gokila VM, Mau JL, Lin CC, Chu FH, Wei CC, Liao VH, Wang SY (2016). A steroid like phytochemical Antcin $M$ is an anti-aging reagent that eliminates hyperglycemia-accelerated premature senescence in dermal fibroblasts by direct activation of Nrf2 and SIRT1. Oncotarget 7(39): 62836-62861. doi: 10.18632/oncotarget.11229

48. Chen W, Sudji IR, Wang E, Joubert E, van Wyk BE, Wink M (2013). Ameliorative effect of aspalathin from rooibos (Aspalathus linearis) on acute oxidative stress in Caenorhabditis elegans. Phytomedicine 20(3-4): 380-386. doi: 10.1016/j.phymed.2012.10.006

49. Havermann S, Rohrig R, Chovolou Y, Humpf HU, Watjen W (2013). Molecular effects of baicalein in Hct116 cells and Caenorhabditis elegans: activation of the Nrf2 signaling pathway and prolongation of lifespan. J Agric Food Chem 61(9): 2158-2164. doi: 10.1021/jf304553g

50. Havermann S, Humpf HU, Watjen W (2016). Baicalein modulates stress-resistance and life span in C. elegans via SKN-1 but not DAF-16. Fitoterapia 113: 123-127. doi: 10.1016/j.fitote.2016.06.018

51. Guerrero-Rubio MA, Hernandez-Garcia S, Garcia-Carmona F, Gandia-Herrero F (2019). Extension of life-span using a RNAi model and in vivo antioxidant effect of Opuntia fruit extracts and pure betalains in Caenorhabditis elegans. Food Chem 274: 840-847. doi: 10.1016/j.foodchem.2018.09.067

52. Rathor L, Pandey R (2018). Age-induced diminution of free radicals by Boeravinone B in Caenorhabditis elegans. Exp Gerontol 111: 94106. doi: 10.1016/j.exger.2018.07.005

53. Lee EB, Xing MM, Kim DK (2017). Lifespan-extending and stress resistance properties of brazilin from Caesalpinia sappan in Caenorhabditis elegans. Arch Pharm Res 40(7): 825-835. doi: 10.1007/s12272-017-0920-3

54. Pietsch K, Saul N, Chakrabarti S, Sturzenbaum SR, Menzel R, Steinberg CE (2011). Hormetins, antioxidants and prooxidants: defining quercetin-, caffeic acid- and rosmarinic acid-mediated life extension in C. elegans. Biogerontology 12(4): 329-347. doi: 10.1007/s10522-011-9334-7

55. Havermann S, Chovolou Y, Humpf HU, Watjen W (2014). Caffeic acid phenethylester increases stress resistance and enhances lifespan in Caenorhabditis elegans by modulation of the insulin-like DAF-16 signalling pathway. PLoS ONE 9(6): e100256. doi: 10.1371/journal.pone.0100256

56. Lublin A, Isoda F, Patel H, Yen K, Nguyen L, Hajje D, Schwartz M, Mobbs C (2011). FDA-approved drugs that protect mammalian neurons from glucose toxicity slow aging dependent on $\mathrm{cbp}$ and protect against proteotoxicity. PLoS ONE 6(11): e27762. doi: 10.1371/journal.pone.0027762

57. Sutphin GL, Bishop E, Yanos ME, Moller RM, Kaeberlein M (2012). Caffeine extends life span, improves healthspan, and delays ageassociated pathology in Caenorhabditis elegans. Longev Healthspan 1 : 9. doi: 10.1186/2046-2395-1-9

58. Bridi JC, Barros AG, Sampaio LR, Ferreira JC, Antunes Soares FA, Romano-Silva MA (2015). Lifespan extension induced by caffeine in Caenorhabditis elegans is partially dependent on adenosine signaling. Front Aging Neurosci 7: 220. doi: 10.3389/fnagi.2015.00220

59. Lu L, Zhao X, Zhang J, Li M, Qi Y, Zhou L (2017). Calycosin promotes lifespan in Caenorhabditis elegans through insulin signaling pathway via daf-16, age-1 and daf-2. J Biosci Bioeng 124(1): 1-7. doi: 10.1016/j.jbiosc.2017.02.021

60. Lin C, Zhang X, Xiao J, Zhong Q, Kuang Y, Cao Y, Chen Y (2019). Effects on longevity extension and mechanism of action of carnosic acid in Caenorhabditis elegans. Food Funct 10(3): 1398-1410. doi: 10.1039/c8fo02371a

61. Saul N, Pietsch K, Menzel R, Sturzenbaum SR, Steinberg CE (2009). Catechin induced longevity in C. elegans: from key regulator genes to disposable soma. Mech Ageing Dev 130(8): 477-486. doi: 10.1016/j.mad.2009.05.005

62. Saul N, Pietsch K, Sturzenbaum SR, Menzel R, Steinberg CE (2011). Diversity of polyphenol action in Caenorhabditis elegans: between toxicity and longevity. J Nat Prod 74(8): 1713-1720. doi: 10.1021/np200011a

63. Jung SK, Aleman-Meza B, Riepe C, Zhong W (2014). QuantWorm: a comprehensive software package for Caenorhabditis elegans phenotypic assays. PLoS ONE 9(1): e84830. doi: 10.1371/journal.pone.0084830

64. Wang E, Wink M (2016). Chlorophyll enhances oxidative stress tolerance in Caenorhabditis elegans and extends its lifespan. PeerJ 4: e1879. doi: 10.7717/peerj.1879

65. Alavez S, Vantipalli MC, Zucker DJ, Klang IM, Lithgow GJ (2011). Amyloid-binding compounds maintain protein homeostasis during ageing and extend lifespan. Nature 472(7342): 226-229. doi: $10.1038 /$ nature09873

66. Liao VH, Yu CW, Chu YJ, Li WH, Hsieh YC, Wang TT (2011). Curcumin-mediated lifespan extension in Caenorhabditis elegans. Mech Ageing Dev 132(10): 480-487. doi: 10.1016/j.mad.2011.07.008

67. Kim YS, Han YT, Jeon H, Cha DS (2018). Antiageing properties of Damaurone D in Caenorhabditis elegans. J Pharm Pharmacol 70(10): 1423-1429. doi: 10.1111/jphp.12979

68. Kim J, Kang YG, Lee JY, Choi DH, Cho YU, Shin JM, Park JS, Lee JH, Kim WG, Seo DB, Lee TR, Miyamoto Y, No KT (2015). The natural phytochemical dehydroabietic acid is an anti-aging reagent that mediates the direct activation of SIRT1. Mol Cell Endocrinol 412: 216225. doi: 10.1016/j.mce.2015.05.006

69. Powolny AA, Singh SV, Melov S, Hubbard A, Fisher AL (2011). The garlic constituent diallyl trisulfide increases the lifespan of $C$. elegans via skn-1 activation. Exp Gerontol 46(6): 441-452. doi: 10.1016/j.exger.2011.01.005

70. Shanmugam G, Mohankumar A, Kalaiselvi D, Nivitha S, Murugesh E, Shanmughavel P, Sundararaj P (2017). Diosgenin a phytosterol substitute for cholesterol, prolongs the lifespan and mitigates glucose toxicity via DAF-16/FOXO and GST-4 in Caenorhabditis elegans. Biomed Pharmacother 95: 1693-1703. doi: 10.1016/j.biopha.2017.09.096

71. Carmona-Gutierrez D, Zimmermann A, Kainz K, Pietrocola F, Chen G, Maglioni S, Schiavi A, Nah J, Mertel S, Beuschel CB, Castoldi F, Sica 
V, Trausinger G, Raml R, Sommer C, Schroeder S, Hofer SJ, Bauer MA, Pendl T, Tadic J, Dammbrueck C, Hu Z, Ruckenstuhl C, Eisenberg T, Durand S, Bossut N, Aprahamian F, Abdellatif M, Sedej S, Enot DP, et al. (2019). The flavonoid 4,4'-dimethoxychalcone promotes autophagy-dependent longevity across species. Nat Commun 10(1): 651. doi: 10.1038/s41467-019-08555-w

72. Wang X, Zhang J, Lu L, Zhou L (2015). The longevity effect of echinacoside in Caenorhabditis elegans mediated through daf- 16 . Biosci Biotechnol Biochem 79(10): 1676-1683. doi: 10.1080/09168451.2015.1046364

73. Chen W, Lin HR, Wei CM, Luo XH, Sun ML, Yang ZZ, Chen XY, Wang $\mathrm{HB}$ (2018). Echinacoside, a phenylethanoid glycoside from Cistanche deserticola, extends lifespan of Caenorhabditis elegans and protects from Abeta-induced toxicity. Biogerontology 19(1): 47-65. doi: 10.1007/s10522-017-9738-0

74. Abbas S, Wink M (2009). Epigallocatechin gallate from green tea (Camellia sinensis) increases lifespan and stress resistance in Caenorhabditis elegans. Planta Med 75(3): 216-221. doi: 10.1055/s0028-1088378

75. Zhang L, Jie G, Zhang J, Zhao B (2009). Significant longevityextending effects of EGCG on Caenorhabditis elegans under stress. Free Radic Biol Med 46(3): 414-421. doi: 10.1016/j.freeradbiomed.2008.10.041

76. Bartholome A, Kampkotter A, Tanner S, Sies H, Klotz LO (2010). Epigallocatechin gallate-induced modulation of FoxO signaling in mammalian cells and $C$. elegans: FoxO stimulation is masked via PI3K/Akt activation by hydrogen peroxide formed in cell culture. Arch Biochem Biophys 501(1): 58-64. doi: 10.1016/j.abb.2010.05.024

77. Zhao X, Lu L, Qi Y, Li M, Zhou L (2017). Emodin extends lifespan of Caenorhabditis elegans through insulin/IGF-1 signaling pathway depending on DAF-16 and SIR-2.1. Biosci Biotechnol Biochem 81(10): 1908-1916. doi: 10.1080/09168451.2017.1365592

78. Zheng J, Heber D, Wang M, Gao C, Heymsfield SB, Martin RJ, Greenway FL, Finley JW, Burton JH, Johnson WD, Enright FM, Keenan MJ, Li Z (2017). Pomegranate juice and extract extended lifespan and reduced intestinal fat deposition in Caenorhabditis elegans. Int J Vitam Nutr Res 87(3-4): 149-158. doi: 10.1024/0300-9831/a000570

79. Sayed AA (2011). Ferulsinaic acid attenuation of advanced glycation end products extends the lifespan of Caenorhabditis elegans. J Pharm Pharmacol 63(3): 423-428. doi: 10.1111/j.20427158.2010.01222.x

80. Kampkötter A, Gombitang Nkwonkam C, Zurawski RF, Timpel C, Chovolou Y, Watjen W, Kahl R (2007). Effects of the flavonoids kaempferol and fisetin on thermotolerance, oxidative stress and FoxO transcription factor DAF-16 in the model organism Caenorhabditis elegans. Arch Toxicol 81(12): 849-858. doi: 10.1007/s00204-0070215-4

81. Vayndorf EM, Lee SS, Liu RH (2013). Whole apple extracts increase lifespan, healthspan and resistance to stress in Caenorhabditis elegans. J Funct Foods 5(3): 1236-1243. doi: 10.1016/j.jff.2013.04.006

82. Wang H, Liu J, Li T, Liu RH (2018). Blueberry extract promotes longevity and stress tolerance via DAF-16 in Caenorhabditis elegans. Food Funct 9(10): 5273-5282. doi: 10.1039/c8fo01680a

83. Yan F, Chen $Y$, Azat $R$, Zheng $X$ (2017). Mulberry anthocyanin extract ameliorates oxidative damage in HepG2 cells and prolongs the lifespan of Caenorhabditis elegans through MAPK and Nrf2 pathways. Oxid Med Cell Longev 2017: 7956158. doi: 10.1155/2017/7956158

84. Wang J, Deng N, Wang H, Li T, Chen L, Zheng B, Liu RH (2020) Effects of orange extracts on longevity, healthspan, and stress resistance in Caenorhabditis elegans. Molecules 25(2): 351 . doi: $10.3390 /$ molecules 25020351
85. Tambara AL, de Los Santos Moraes L, Dal Forno AH, Boldori JR, Goncalves Soares AT, de Freitas Rodrigues C, Mariutti LRB, Mercadante AZ, de Avila DS, Denardin CC (2018). Purple pitanga fruit (Eugenia uniflora L.) protects against oxidative stress and increase the lifespan in Caenorhabditis elegans via the DAF-16/FOXO pathway. Food Chem Toxicol 120: 639-650. doi: 10.1016/j.fct.2018.07.057

86. Cuong VT, Chen W, Shi J, Zhang M, Yang H, Wang N, Yang S, Li J, Yang P, Fei J (2019). The anti-oxidation and anti-aging effects of Ganoderma lucidum in Caenorhabditis elegans. Exp Gerontol 117: 99105. doi: 10.1016/j.exger.2018.11.016

87. Lee EB, Ahn D, Kim BJ, Lee SY, Seo HW, Cha YS, Jeon H, Eun JS, Cha DS, Kim DK (2015). Genistein from Vigna angularis extends lifespan in Caenorhabditis elegans. Biomol Ther 23(1): 77-83. doi: 10.4062/biomolther.2014.075

88. Shintani $T$, Kosuge $Y$, Ashida $H$ (2018). Glucosamine extends the lifespan of Caenorhabditis elegans via autophagy induction. J Appl Glycosci 65(3): 37-43. doi: 10.5458/jag.jag.JAG-2018_002

89. Zarse K, Bossecker A, Muller-Kuhrt L, Siems K, Hernandez MA, Berendsohn WG, Birringer M, Ristow M (2011). The phytochemical glaucarubinone promotes mitochondrial metabolism, reduces body fat, and extends lifespan of Caenorhabditis elegans. Horm Metab Res 43(4): 241-243. doi: 10.1055/s-0030-1270524

90. Liu H, Liang F, Su W, Wang N, Lv M, Li P, Pei Z, Zhang Y, Xie XQ, Wang L, Wang $Y$ (2013). Lifespan extension by $n$-butanol extract from seed of Platycladus orientalis in Caenorhabditis elegans. J Ethnopharmacol 147(2): 366-372. doi: 10.1016/j.jep.2013.03.019

91. Honda $Y$, Fujita $Y$, Maruyama H, Araki Y, Ichihara K, Sato A, Kojima $T$, Tanaka M, Nozawa $Y$, Ito M, Honda S (2011). Lifespan-extending effects of royal jelly and its related substances on the nematode Caenorhabditis elegans. PLoS ONE 6(8): e23527. doi: 10.1371/journal.pone.0023527

92. Cai WJ, Huang JH, Zhang SQ, Wu B, Kapahi P, Zhang XM, Shen ZY (2011). Icariin and its derivative icariside II extend healthspan via insulin/IGF-1 pathway in C. elegans. PLoS ONE 6(12): e28835. doi: 10.1371/journal.pone.0028835

93. Surco-Laos F, Cabello J, Gomez-Orte E, Gonzalez-Manzano S, Gonzalez-Paramas AM, Santos-Buelga C, Duenas M (2011). Effects of O-methylated metabolites of quercetin on oxidative stress, thermotolerance, lifespan and bioavailability on Caenorhabditis elegans. Food Funct 2(8): 445-456. doi: 10.1039/c1fo10049a

94. Grünz G, Haas K, Soukup S, Klingenspor M, Kulling SE, Daniel H, Spanier B (2012). Structural features and bioavailability of four flavonoids and their implications for lifespan-extending and antioxidant actions in C. elegans. Mech Ageing Dev 133(1): 1-10. doi: 10.1016/j.mad.2011.11.005

95. Buchter C, Ackermann D, Honnen S, Arnold N, Havermann S, Koch K, Watjen W (2015). Methylated derivatives of myricetin enhance life span in Caenorhabditis elegans dependent on the transcription factor DAF-16. Food Funct 6(10): 3383-3392. doi: 10.1039/c5fo00463b

96. Su S, Wink M (2015). Natural lignans from Arctium lappa as antiaging agents in Caenorhabditis elegans. Phytochemistry 117: 340350. doi: 10.1016/j.phytochem.2015.06.021

97. Jahn A, Scherer B, Fritz G, Honnen S (2020). Statins induce a DAF16/Foxo-dependent longevity phenotype via JNK-1 through mevalonate depletion in C. elegans. Aging Dis 11(1): 60-72. doi: 10.14336/AD.2019.0416

98. Onken B, Driscoll M (2010). Metformin induces a dietary restriction-like state and the oxidative stress response to extend $C$. elegans healthspan via AMPK, LKB1, and SKN-1. PLoS ONE 5(1): e8758. doi: 10.1371/journal.pone.0008758 
99. Cabreiro F, Au C, Leung KY, Vergara-Irigaray N, Cocheme HM, Noori T, Weinkove D, Schuster E, Greene ND, Gems D (2013). Metformin retards aging in $C$. elegans by altering microbial folate and methionine metabolism. Cell 153(1): 228-239. doi: 10.1016/j.cell.2013.02.035

100. Chen J, Ou Y, Li Y, Hu S, Shao LW, Liu Y (2017). Metformin extends $C$. elegans lifespan through lysosomal pathway. Elife 6. doi: 10.7554/eLife. 31268

101. Shi YC, Pan TM, Liao VH (2016). Monascin from monascusfermented products reduces oxidative stress and amyloid-beta toxicity via DAF-16/FOXO in Caenorhabditis elegans. J Agric Food Chem 64(38): 7114-7120. doi: 10.1021/acs.jafc.6b02779

102. Büchter C, Ackermann D, Havermann S, Honnen S, Chovolou Y, Fritz G, Kampkötter A, Watjen W (2013). Myricetin-mediated lifespan extension in Caenorhabditis elegans is modulated by DAF-16. Int J Mol Sci 14(6): 11895-11914. doi: 10.3390/ijms140611895

103. Jung HY, Lee D, Ryu HG, Choi BH, Go Y, Lee N, Son HG, Jeon J, Kim SH, Yoon JH, Park SM, Lee SV, Lee IK, Choi KY, Ryu SH, Nohara K, Yoo $\mathrm{SH}$, Chen Z, Kim KT (2017). Myricetin improves endurance capacity and mitochondrial density by activating SIRT1 and PGC-1alpha. Sci Rep 7(1): 6237. doi: 10.1038/s41598-017-05303-2

104. Tezil T, Chamoli M, Ng CP, Simon RP, Butler VJ, Jung M, Andersen J, Kao AW, Verdin E (2019). Lifespan-increasing drug nordihydroguaiaretic acid inhibits p300 and activates autophagy. NPJ Aging Mech Dis 5: 7. doi: 10.1038/s41514-019-0037-7

105. Shamalnasab M, Gravel SP, St-Pierre J, Breton L, Jager S, Aguilaniu $H$ (2018). A salicylic acid derivative extends the lifespan of Caenorhabditis elegans by activating autophagy and the mitochondrial unfolded protein response. Aging Cell 17(6): e12830. doi: 10.1111/acel.12830

106. Zhang J, Lu L, Zhou L (2015). Oleanolic acid activates daf-16 to increase lifespan in Caenorhabditis elegans. Biochem Biophys Res Commun 468(4): 843-849. doi: 10.1016/j.bbrc.2015.11.042

107. Shen $P$, Yue $Y$, Sun $Q$, Kasireddy N, Kim KH, Park $Y$ (2017). Piceatannol extends the lifespan of Caenorhabditis elegans via DAF-16. Biofactors 43(3): 379-387. doi: 10.1002/biof.1346

108. Upadhyay A, Chompoo J, Taira N, Fukuta M, Tawata S (2013). Significant longevity-extending effects of Alpinia zerumbet leaf extract on the life span of Caenorhabditis elegans. Biosci Biotechnol Biochem 77(2): 217-223. doi: 10.1271/bbb.120351

109. Duangjan C, Rangsinth P, Gu X, Wink M, Tencomnao T (2019). Lifespan extending and oxidative stress resistance properties of a leaf extracts from Anacardium occidentale L. in Caenorhabditis elegans. Oxid Med Cell Longev 2019: 9012396. doi: 10.1155/2019/9012396

110. Pandey S, Phulara SC, Mishra SK, Bajpai R, Kumar A, Niranjan A, Lehri A, Upreti DK, Chauhan PS (2020). Betula utilis extract prolongs life expectancy, protects against amyloid-beta toxicity and reduces alpha synuclien in Caenorhabditis elegans via DAF-16 and SKN-1. Comp Biochem Physiol C Toxicol Pharmacol 228: 108647. doi: 10.1016/j.cbpc.2019.108647

111. Fei T, Fei J, Huang F, Xie T, Xu J, Zhou Y, Yang P (2017). The antiaging and anti-oxidation effects of tea water extract in Caenorhabditis elegans. Exp Gerontol 97: 89-96. doi: 10.1016/j.exger.2017.07.015

112. Rangsinth P, Prasansuklab A, Duangjan C, Gu X, Meemon K, Wink $\mathrm{M}$, Tencomnao $\mathrm{T}$ (2019). Leaf extract of Caesalpinia mimosoides enhances oxidative stress resistance and prolongs lifespan in Caenorhabditis elegans. BMC Complement Altern Med 19(1): 164. doi: 10.1186/s12906-019-2578-5

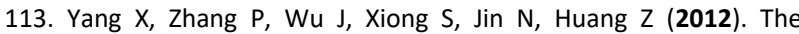
neuroprotective and lifespan-extension activities of Damnacanthus officinarum extracts in Caenorhabditis elegans. J Ethnopharmacol 141(1): 41-47. doi: 10.1016/j.jep.2012.01.025

114. Govindan S, Amirthalingam M, Duraisamy K, Govindhan T, Sundararaj N, Palanisamy S (2018). Phytochemicals-induced hormesis protects Caenorhabditis elegans against alpha-synuclein protein aggregation and stress through modulating HSF-1 and SKN-1/Nrf2 signaling pathways. Biomed Pharmacother 102: 812-822. doi: 10.1016/j.biopha.2018.03.128

115. Huang $\mathrm{CH}$, Hsu FY, Wu YH, Zhong L, Tseng MY, Kuo CJ, Hsu AL, Liang SS, Chiou SH (2015). Analysis of lifespan-promoting effect of garlic extract by an integrated metabolo-proteomics approach. J Nutr Biochem 26(8): 808-817. doi: 10.1016/j.jnutbio.2015.02.010

116. Wu Z, Smith JV, Paramasivam V, Butko P, Khan I, Cypser JR, Luo Y (2002). Ginkgo biloba extract EGb 761 increases stress resistance and extends life span of Caenorhabditis elegans. Cell Mol Biol 48(6): 725731. PMID: 12396085

117. Kampkötter A, Pielarski T, Rohrig R, Timpel C, Chovolou Y, Watjen W, Kahl R (2007). The Ginkgo biloba extract EGb761 reduces stress sensitivity, ROS accumulation and expression of catalase and glutathione S-transferase 4 in Caenorhabditis elegans. Pharmacol Res 55(2): 139-147. doi: 10.1016/j.phrs.2006.11.006

118. Duangjan C, Rangsinth $P, G u X$, Zhang S, Wink M, Tencomnao T (2019). Glochidion zeylanicum leaf extracts exhibit lifespan extending and oxidative stress resistance properties in Caenorhabditis elegans via DAF-16/FoxO and SKN-1/Nrf-2 signaling pathways. Phytomedicine 64: 153061. doi: 10.1016/j.phymed.2019.153061

119. Peixoto $H$, Roxo M, Rohrig $T$, Richling E, Wang X, Wink M (2017). Anti-aging and antioxidant potential of Paullinia cupana var. sorbilis: Findings in Caenorhabditis elegans indicate a new utilization for roasted seeds of guarana. Medicines 4(3). doi: 10.3390/medicines4030061

120. Koch K, Weldle N, Baier S, Buchter C, Watjen W (2020). Hibiscus sabdariffa $\mathrm{L}$. extract prolongs lifespan and protects against amyloidbeta toxicity in Caenorhabditis elegans: involvement of the FoxO and Nrf2 orthologues DAF-16 and SKN-1. Eur J Nutr 59(1): 137-150. doi: 10.1007/s00394-019-01894-w

121. Yang ZZ, Yu YT, Lin HR, Liao DC, Cui XH, Wang HB (2018). Lonicera japonica extends lifespan and healthspan in Caenorhabditis elegans. Free Radic Biol Med 129: 310-322. doi: 10.1016/j.freeradbiomed.2018.09.035

122. Jeon H, Cha DS (2016). Anti-aging properties of Ribes fasciculatum in Caenorhabditis elegans. Chin J Nat Med 14(5): 335342. doi: 10.3724/SP.J.1009.2016.00335

123. Ergen N, Hosbas S, Deliorman Orhan D, Aslan M, Sezik E, Atalay A (2018). Evaluation of the lifespan extension effects of several Turkish medicinal plants in Caenorhabditis elegans. Turk J Biol 42(2): 163-173. doi: 10.3906/biy-1711-5

124. Wen H, Gao X, Qin J (2014). Probing the anti-aging role of polydatin in Caenorhabditis elegans on a chip. Integr Biol 6(1): 35-43. doi: 10.1039/c3ib40191j

125. Zhang H, Pan N, Xiong S, Zou S, Li H, Xiao L, Cao Z, Tunnacliffe A, Huang $Z$ (2012). Inhibition of polyglutamine-mediated proteotoxicity by Astragalus membranaceus polysaccharide through the DAF16/FOXO transcription factor in Caenorhabditis elegans. Biochem J 441(1): 417-424. doi: 10.1042/BJ20110621

126. Fang Z, Chen Y, Wang G, Feng T, Shen M, Xiao B, Gu J, Wang W, Li J, Zhang $Y$ (2019). Evaluation of the antioxidant effects of acid hydrolysates from Auricularia auricular polysaccharides using a Caenorhabditis elegans model. Food Funct 10(9): 5531-5543. doi: 10.1039/c8fo02589d 
127. Pannakal ST, Jager $S$, Duranton A, Tewari A, Saha S, Radhakrishnan A, Roy N, Kuntz JF, Fermas S, James D, Mellor J, Misra $\mathrm{N}$, Breton L (2017). Longevity effect of a polysaccharide from Chlorophytum borivilianum on Caenorhabditis elegans and Saccharomyces cerevisiae. PLoS ONE 12(7): e0179813. doi: 10.1371/journal.pone.0179813

128. Liu X, Huang $Y$, Chen $Y$, Cao $Y$ (2016). Partial structural characterization, as well as immunomodulatory and anti-aging activities of CP2-c2-s2 polysaccharide from Cordyceps militaris. RSC Adv 6(106): 104094. doi: 10.1039/C6RA23612J

129. Feng $S$, Cheng $H, X u Z$, Shen $S$, Yuan M, Liu J, Ding $C$ (2015). Thermal stress resistance and aging effects of Panax notoginseng polysaccharides on Caenorhabditis elegans. Int J Biol Macromol 81: 188-194. doi: 10.1016/j.ijbiomac.2015.07.057

130. Chuang MH, Chiou SH, Huang CH, Yang WB, Wong CH (2009). The lifespan-promoting effect of acetic acid and Reishi polysaccharide. Bioorg Med Chem 17(22): 7831-7840. doi 10.1016/j.bmc.2009.09.002

131. Yuan $Y$, Kang N, Li Q, Zhang Y, Liu Y, Tan P (2019). Study of the effect of neutral polysaccharides from Rehmannia glutinosa on lifespan of Caenorhabditis elegans. Molecules 24(24): 4592. doi: 10.3390/molecules24244592

132. Sunagawa T, Shimizu T, Kanda T, Tagashira M, Sami M, Shirasawa $\mathrm{T}$ (2011). Procyanidins from apples (Malus pumila Mill.) extend the lifespan of Caenorhabditis elegans. Planta Med 77(2): 122-127. doi: 10.1055/s-0030-1250204

133. Wilson MA, Shukitt-Hale B, Kalt W, Ingram DK, Joseph JA, Wolkow CA (2006). Blueberry polyphenols increase lifespan and thermotolerance in Caenorhabditis elegans. Aging Cell 5(1): 59-68. doi: 10.1111/j.1474-9726.2006.00192.x

134. Martorell P, Forment JV, de Llanos R, Monton F, Llopis S, Gonzalez N, Genoves S, Cienfuegos E, Monzo H, Ramon D (2011). Use of Saccharomyces cerevisiae and Caenorhabditis elegans as model organisms to study the effect of cocoa polyphenols in the resistance to oxidative stress. J Agric Food Chem 59(5): 2077-2085. doi: 10.1021/jf104217g

135. Kampkötter A, Nkwonkam CG, Zurawski RF, Timpel C, Chovolou Y, Watjen W, Kahl R (2007). Investigations of protective effects of the flavonoids quercetin and rutin on stress resistance in the model organism Caenorhabditis elegans. Toxicol 234(1-2): 113-123. doi: 10.1016/j.tox.2007.02.006

136. Kampkötter A, Timpel C, Zurawski RF, Ruhl S, Chovolou Y, Proksch $P$, Watjen W (2008). Increase of stress resistance and lifespan of Caenorhabditis elegans by quercetin. Comp Biochem Physiol B Biochem Mol Biol 149(2): 314-323. doi: 10.1016/j.cbpb.2007.10.004

137. Saul N, Pietsch K, Menzel R, Steinberg CE (2008). Quercetinmediated longevity in Caenorhabditis elegans: is DAF-16 involved? Mech Ageing Dev 129(10): 611-613. doi: 10.1016/j.mad.2008.07.001

138. Pietsch K, Saul N, Menzel R, Sturzenbaum SR, Steinberg CE (2009). Quercetin mediated lifespan extension in Caenorhabditis elegans is modulated by age-1, daf-2, sek-1 and unc-43. Biogerontol 10(5): 565578. doi: 10.1007/s10522-008-9199-6

139. Duenas M, Surco-Laos F, Gonzalez-Manzano S, Gonzalez-Paramas AM, Gomez-Orte E, Cabello J, Santos-Buelga C (2013). Deglycosylation is a key step in biotransformation and lifespan effects of quercetin-3O-glucoside in Caenorhabditis elegans. Pharmacol Res 76: 41-48. doi: 10.1016/j.phrs.2013.07.001

140. Zhang L, Zhang J, Zhao B, Zhao-Wilson X (2012). Quinic acid could be a potential rejuvenating natural compound by improving survival of Caenorhabditis elegans under deleterious conditions. Rejuvenation Res 15(6): 573-583. doi: 10.1089/rej.2012.1342
141. Srivastava D, Arya U, SoundaraRajan T, Dwivedi H, Kumar S, Subramaniam JR (2008). Reserpine can confer stress tolerance and lifespan extension in the nematode $C$. elegans. Biogerontology 9(5): 309-316. doi: 10.1007/s10522-008-9139-5

142. Wood JG, Rogina B, Lavu S, Howitz K, Helfand SL, Tatar M, Sinclair $D$ (2004). Sirtuin activators mimic caloric restriction and delay ageing in metazoans. Nature 430(7000): 686-689. doi: 10.1038/nature02789

143. Viswanathan M, Kim SK, Berdichevsky A, Guarente L (2005). A role for SIR-2.1 regulation of ER stress response genes in determining C. elegans life span. Dev Cell 9(5): 605-615. doi: 10.1016/j.devcel.2005.09.017

144. Bass TM, Weinkove D, Houthoofd K, Gems D, Partridge L (2007). Effects of resveratrol on lifespan in Drosophila melanogaster and Caenorhabditis elegans. Mech Ageing Dev 128(10): 546-552. doi: 10.1016/j.mad.2007.07.007

145. Gruber J, Tang SY, Halliwell B (2007). Evidence for a trade-off between survival and fitness caused by resveratrol treatment of Caenorhabditis elegans. Ann N Y Acad Sci 1100: 530-542. doi: 10.1196/annals.1395.059

146. Morselli E, Maiuri MC, Markaki M, Megalou E, Pasparaki A, Palikaras K, Criollo A, Galluzzi L, Malik SA, Vitale I, Michaud M, Madeo $\mathrm{F}$, Tavernarakis N, Kroemer $\mathrm{G}$ (2010). Caloric restriction and resveratrol promote longevity through the Sirtuin-1-dependent induction of autophagy. Cell Death Dis 1(1): e10. doi: 10.1038/cddis.2009.8

147. Banse SA, Lucanic M, Sedore CA, Coleman-Hulbert AL, Plummer WT, Chen E, Kish JL, Hall D, Onken B, Presley MP, Jones EG, Blue BW, Garrett T, Abbott M, Xue J, Guo S, Johnson E, Foulger AC, Chamoli M, Falkowski R, Melentijevic I, Harinath G, Huynh P, Patel S, Edgar D, Jarrett CM, Guo M, Kapahi P, Lithgow GJ, Driscoll M, et al. (2019). Automated lifespan determination across Caenorhabditis strains and species reveals assay-specific effects of chemical interventions. Geroscience 41(6): 945-960. doi: 10.1007/s11357-019-00108-9

148. Lin C, Xiao J, Xi Y, Zhang X, Zhong Q, Zheng H, Cao Y, Chen $Y$ (2019). Rosmarinic acid improved antioxidant properties and healthspan via the IIS and MAPK pathways in Caenorhabditis elegans. Biofactors 45(5): 774-787. doi: 10.1002/biof.1536

149. Ogawa T, Kodera Y, Hirata D, Blackwell TK, Mizunuma M (2016). Natural thioallyl compounds increase oxidative stress resistance and lifespan in Caenorhabditis elegans by modulating SKN-1/Nrf. Sci Rep 6: 21611. doi: 10.1038/srep21611

150. Eisenberg T, Knauer H, Schauer A, Buttner S, Ruckenstuhl C, Carmona-Gutierrez D, Ring J, Schroeder S, Magnes C, Antonacci L, Fussi H, Deszcz L, Hartl R, Schraml E, Criollo A, Megalou E, Weiskopf D, Laun $P$, Heeren $G$, Breitenbach $M$, Grubeck-Loebenstein B, Herker $E$, Fahrenkrog B, Frohlich KU, Sinner F, Tavernarakis N, Minois N, Kroemer G, Madeo $F$ (2009). Induction of autophagy by spermidine promotes longevity. Nat Cell Biol 11(11): 1305-1314. doi: 10.1038/ncb1975

151. Srivastava S, Sammi SR, Laxman TS, Pant A, Nagar A, Trivedi S, Bhatta RS, Tandon S, Pandey R (2017). Silymarin promotes longevity and alleviates Parkinson's associated pathologies in Caenorhabditis elegans. J Funct Foods 31: 32-43. doi: 10.1016/j.jff.2017.01.029

152. Pandey T, Sammi SR, Nooreen Z, Mishra A, Ahmad A, Bhatta RS, Pandey $R$ (2019). Anti-ageing and anti-Parkinsonian effects of natural flavonol, tambulin from Zanthoxyllum aramatum promotes longevity in Caenorhabditis elegans. Exp Gerontol 120: 50-61. doi: 10.1016/j.exger.2019.02.016

153. Saul N, Pietsch K, Menzel R, Sturzenbaum SR, Steinberg CE (2010). The longevity effect of tannic acid in Caenorhabditis elegans: disposable soma meets hormesis. J Gerontol A Biol Sci Med Sci 65(6): 626-635. doi: 10.1093/gerona/glq051 
154. Edwards C, Canfield J, Copes N, Brito A, Rehan M, Lipps D, Brunquell J, Westerheide SD, Bradshaw PC (2015). Mechanisms of amino acid-mediated lifespan extension in Caenorhabditis elegans. BMC Genet 16: 8. doi: 10.1186/s12863-015-0167-2

155. Zarse K, Jabin S, Ristow M (2012). L-Theanine extends lifespan of adult Caenorhabditis elegans. Eur J Nutr 51(6): 765-768. doi: 10.1007/s00394-012-0341-5

156. Adachi $H$, Ishii $N$ (2000). Effects of tocotrienols on life span and protein carbonylation in Caenorhabditis elegans. J Gerontol A Biol Sci Med Sci 55(6): B280-285. doi: 10.1093/gerona/55.6.b280

157. Fang EF, Waltz TB, Kassahun $H$, Lu Q, Kerr JS, Morevati $M$, Fivenson EM, Wollman BN, Marosi K, Wilson MA, Iser WB, Eckley DM, Zhang Y, Lehrmann E, Goldberg IG, Scheibye-Knudsen M, Mattson MP, Nilsen H, Bohr VA, Becker KG (2017). Tomatidine enhances lifespan and healthspan in $C$. elegans through mitophagy induction via the SKN-1/Nrf2 pathway. Sci Rep 7: 46208. doi: 10.1038/srep46208
158. Honda Y, Tanaka M, Honda S (2010). Trehalose extends longevity in the nematode Caenorhabditis elegans. Aging Cell 9(4): 558-569. doi: 10.1111/j.1474-9726.2010.00582.x

159. Kim SJ, Beak SM, Park SK (2017). Supplementation with triptolide increases resistance to environmental stressors and lifespan in $C$. elegans. J Food Sci 82(6): 1484-1490. doi: 10.1111/1750-3841.13720

160. Negi H, Saikia SK, Pandey R (2017). 3beta-Hydroxy-urs-12-en-28oic acid modulates dietary restriction mediated longevity and ameliorates toxic protein aggregation in C. elegans. J Gerontol A Biol Sci Med Sci 72(12): 1614-1619. doi: 10.1093/gerona/glx118

161. Tiku V, Jain C, Raz Y, Nakamura S, Heestand B, Liu W, Spath M, Suchiman HED, Muller RU, Slagboom PE, Partridge L, Antebi A (2017). Small nucleoli are a cellular hallmark of longevity. Nat Commun 8: 16083. doi: 10.1038/ncomms16083 